\title{
Dora Mayer, los indígenas y la nación peruana a inicios del siglo $\mathrm{XX}^{1 /}$
}

\section{Dora Mayer, the Indian People of Peru, and the Peruvian Nation in the Early Twentieth Century}

\author{
Margarita Zegarra Flórez
}

Oficina Nacional de Procesos Electorales (ONPE), Perú

En el artículo se abordan los planteamientos que la periodista Dora Mayer hiciera sobre la "cuestión indígena" y la nación peruana, en una etapa de profundos conflictos sociales surgidos en un entorno de modernización económica sustentada sobre relaciones laborales premodernas y opresión indígena. Reconstruimos su visión sobre cómo debía ser la relación entre los componentes de la nación peruana, sus críticas a la exclusión indígena y sus advertencias sobre las repercusiones disociadoras que ésta última tenía. El propósito central es reflexionar sobre el impacto de la doble labor de formación de conciencia crítica de la opinión pública y de educación cívica de los indígenas, que llevó a cabo Dora Mayer desde El Deber Pro-Indígena (1912-1917).

Palabras Clave: Indigenismo; Nación; Perú; Siglo XX; Periodismo; Mujer.

This article analyses the expositions that the journalist Dora Mayer did regarding the "indigenous question" and the Peruvian nation, in a stage of deep social conflicts that take place in a context of economic modernization sustained on pre-modern labor relationships and indigenous oppression. We reconstructed her vision on how the relation between the components of the Peruvian Nation had to be, her critics towards indigenous exclusion and her warnings on the repercussions that the latter one had. The main purpose is to think about the impact of the double formation on critical conscience of the public opinion, as well as on civic education of the indigenous people that Dora Mayer did in El Deber ProIndígena (1912-1917).

KEYwORDS: Indigenismo; Nation; Peru; XX Century; Journalism; Woman.

1 Una versión primera de este trabajo fue presentada como ponencia en el LII Congreso Internacional de Americanistas. Pueblos y Culturas de la Américas: diálogos entre globalidad y localidad (Sevilla, 17-21 de julio de 2006), dentro del Simposio HIST38. "Rescuing Andean Cultures and Nations. Against Exclusion and Repression after 1750", coordinado por Scarlett O'Phelan Godoy y Erick Langer. 


\section{Introducción}

En los últimos años del siglo XIX, la historia política reciente de derrota y ocupación del país y de luchas entre los caudillos militares, fue leída en clave positivista, quedando en evidencia la debilidad del Estado peruano, así como lo inacabado del proceso de formación de la nación. Un sector de las elites intelectuales y políticas coincidió en que era imperioso forjar un Estado capaz de asumir algunas funciones públicas y de asentar la economía sobre bases más sólidas, para constituir al Perú como una nación moderna. Se impulsó un proyecto modernizador que daría lugar, en las siguientes décadas, a grandes transformaciones políticas, económicas, sociales y culturales. La aspiración de construir una nación moderna que pusiera al Perú al nivel de los países "civilizados" llevó a reexaminar críticamente sus componentes y a redefinir inclusiones y exclusiones de segmentos de la población. En estas reflexiones participó activamente Dora Mayer (1868-1951), una mujer de clase media de origen alemán, identificada profundamente con el Perú.

El presente estudio busca explorar los planteamientos de Dora Mayer sobre la "cuestión indígena" y la nación peruana, que publicara en el periódico que ella dirigió, El Deber Pro-Indígena (octubre 1912-noviembre 1917), órgano de la Asociación Pro-Indígena. Ubicaremos la formación de Dora Mayer en una sociedad en la que coexistían la modernización económica con visiones racistas y legislación excluyente. Profundizaremos en los objetivos, miembros, estructura y trabajo de la asociación que fundara con Pedro Zulen en años especialmente duros para la población indígena. A través de su pluma crítica, nos acercaremos a las denuncias indígenas de los atropellos de que eran objeto y a la visión de Mayer acerca de la repercusión que ello tenía sobre el cuerpo de la nación. Conoceremos su visión sobre qué actores podían transformar la servidumbre indígena, su progresivo escepticismo respecto al valor de la democracia representativa para el Perú y su análisis de los difíciles dilemas que la opresión indígena planteaba. El objeto final del presente trabajo es llamar la atención sobre una valiosa intelectual peruana cuyas demandas a la sociedad y el Estado, para incluir a los indígenas como parte relevante de la nación peruana, generaron una corriente de opinión pública favorable a las comunidades indígenas e incrementaron su capacidad de autodefensa. 


\section{El camino de Dora Mayer hacia la opresión indígena}

Algunos elementos de la vida personal de esta mujer la prepararon para desarrollar una visión crítica frente a la opresión de su época y para su compromiso intelectual y vital con causas sociales. En los años de la fundación de la Asociación Pro-Indígena (1909), Dora Mayer era una fémina de mediana edad, autodidacta, soltera, de clase media, sumamente culta, disciplinada y moral. Había llegado al Perú a los 4 años de edad ${ }^{2}$ junto con sus padres, quienes abandonaron para siempre su Hamburgo natal y la ciudadanía alemana, en protesta contra el nuevo orden político prusiano. Si bien Dora Mayer nunca viajó a Alemania, mantuvo importantes lazos con su tierra de origen: educación alemana, espiritualidad luterana, lecturas, comunicación epistolar con familiares y, sobre todo, una permanente mirada sobre Alemania, cuya creciente militarización y beligerancia la llevarán a escribir numerosos ensayos.

Su educación corrió a cargo de su madre, quien le enseñó hábitos disciplinados de lectura y reflexión desarrollados en la actualizada biblioteca familiar. Por ello su infancia y juventud estuvieron marcadas por la lectura, aspecto favorecido por el marcado aislamiento social en que la mantuvieron sus padres. La severidad y el dominio materno sobre Dora, prolongado debido a su soltería, inició en ella "un ansia de libertad que me ha conducido a comprender los sufrimientos de los pueblos oprimidos del mundo, a cuya causa debí mas tarde dedicar las luchas de mi pluma". ${ }^{3}$ De su padre liberal, Dora Mayer aprendió a expresar su opinión con valentía y a creer que, más allá del sexo o el status social, todo ser humano podía dejar huella en la sociedad. ${ }^{4}$ Formada dentro de la tradición austera de la moral luterana y del liberalismo alemán, tuvo como valores el orden, la disciplina, la dedicación al estudio y la solidaridad con las causas sociales. Sus influencias estéticas, intelectuales y morales se unieron a sus habilidades literarias, haciendo de ella una escritora de carácter o, en sus términos, una "escritora moralis-

2 Los datos biográficos de Dora Mayer los hemos extraído del texto autobiográfico que escribió entre 1947 y 1951. Mayer de Zulen, Dora: Memorias. Universidad N. M. San Marcos, Lima, 1992 (1951-1952), 3 volúmenes. Y en algunos aspectos, del artículo de Cárdenas Timoteo, Clara Matilde: "Dora Mayer de Zulen: apuntes para un estudio de su vida y obra", en Perú Indígena, n. ${ }^{\circ} 27$, Lima 1988, págs. 141-163.

3 Opinaba que así como las jóvenes que se casaban adquirían su independencia, las solteras también deberían obtenerla, y no vivir siempre como menores bajo las órdenes de sus mayores. Mayer de Zulen, Memorias, vol. II, pág. 207.

4 Cárdenas, "Dora Mayer de Zulen: apuntes para un estudio de su vida y obra”, págs. 141-163. 
ta". ${ }^{5}$ Se autoeducó, constituyéndose en una intelectual interesada en formar una opinión pública consciente de los grandes problemas del país. Su peruanidad, vivida con un patriotismo intenso que se evidencia en su campaña indigenista y en sus escritos por la recuperación de Tacna y Arica, fue un acto de voluntad y de compromiso con "nuestra patria", "nuestros indios".

Con el nuevo siglo, Dora Mayer inició su participación en el espacio público limeño, a través de formas de sociabilidad moderna que eran utilizadas por contadas mujeres: las conferencias, la pertenencia a asociaciones civiles y, sobre todo, la escritura; a esta última actividad se dedicaría toda su vida. Es de destacar lo peculiar de su vigorosa actuación pública en un ambiente intelectual como el limeño de inicios del siglo XX, en el que participaban aún pocas mujeres, no siendo fácil debido a los prejuicios frente a la capacidad femenina y a la idea ilustrada de un rol fundamentalmente doméstico y maternal que las excluía del espacio público. La sorprendente independencia de criterio que encontraremos en los escritos de Dora Mayer, se debió en mucho a su tesón personal, pero también a características suyas que la "des-mujerizaban" e inclusive funcionaban como ventajas comparativas: ser racional, culta, corresponsal de periódicos extranjeros y peruanos y, finalmente, su origen alemán, país que simbolizaba el progreso, la pujan$\mathrm{za}$, la raza superior.

Mayer empezó a escribir y exponer sus puntos de vista sobre la sociedad peruana, iniciando en 1900 su colaboración con el prestigioso periódico El Comercio, que se prolongaría durante más de 50 años. En 1905 publicó uno de sus tempranos artículos indigenistas, "Reflexiones Amargas", en El Indio; en 1907 escribió que no buscaba la redención de los oprimidos en general, sino la "de los hijos del Inca" ${ }^{6}$ Ese mismo año apareció una serie de ensayos suyos bajo el título de Estudios sociológicos y, en 1908, su ensayo El objeto de la legislación. Cabe enfatizar que la Sociología inspiraba sus pensamientos; creía en la ley del progreso desarrollada por el positivismo, así como en la teoría de Darwin de la evolución científica. Sostuvo la necesidad de otorgar derechos civiles a las mujeres, ${ }^{7}$ pero el sector social

5 Mayer de Zulen, Memorias, vol. I, págs. 101-102.

6 Rénique, José Luis: La batalla por Puno. Conflicto agrario y nación en los Andes peruanos, 1866-1995. IEP/SUR/CEPES, Lima, 2004, pág. 66.

7 Escribió que la legislación europea había sido muy injusta hacia el sexo femenino, lo que había dado lugar al poderoso movimiento feminista, que estaba en pleno desarrollo. No creía necesario dar sufragio a la mujer, aunque sí los derechos civiles ("la personería jurídica"), pues los intereses materiales de esta eran tan sagrados como los del hombre. Mayer, Dora: El objeto de la legislación. Imprenta del H. Concejo Provincial, El Callao, 1908, págs. 64-65. 
cuya exclusión la comprometió más profundamente fue la población indígena. En 1909 fundó, junto a Pedro Zulen, la Asociación Pro-Indígena, que llegaría a ser la más importante institución indigenista en el Perú y en la que ella cumpliría un papel destacado.

¿Cuál era la problemática de la población indígena, que motivó el compromiso intelectual y vital de Dora Mayer? En los años iniciales del siglo XX, predominaban en muchos espacios del país relaciones sociales serviles que no se condecían con los planteamientos liberales. Estaban basadas en formas productivas premodernas, como la servidumbre indígena en las extensas y tradicionales haciendas de la sierra y en los domicilios de la clase alta urbana, y la semiesclavitud indígena en las zonas de selva dedicadas a la explotación del caucho. Las relaciones serviles también se hacían presentes en sistemas de reclutamiento de trabajadores indígenas por coacción o engaño (por ejemplo, el enganche) en las modernas haciendas agroexportadoras de la costa y en la minería de exportación. Tal situación se veía facilitada por la relativa autonomía de las regiones frente al poder central. Pero también por un Estado que, si bien se volvía menos patrimonial, no incorporaba en su modernización a las mayorías indígenas, postura justificada en la ideología del racismo científico. ${ }^{8}$ Tanto la elite tradicional como sectores de la propia elite modernizadora legitimaron sus privilegios en la idea científicamente prestigiosa de su superioridad racial. Y algunos intelectuales positivistas de esos sectores conceptuaron a la población indígena como una raza inferior por la ley de la herencia, la que introducía en ella factores atávicos, que la convertían en una perniciosa influencia sobre el "carácter nacional". Frente a la herencia difícilmente modificable que traía consigo la "raza indígena", había como escribiría Javier Prado en 1894- "impotencia del progreso ante la fuerza repulsiva de una civilización paralizada y de un pueblo agotado" por el sufrimiento. ${ }^{9}$ El planteamiento de Prado sobre esa raza inviable influyó mucho en la Universidad de San Marcos, dando pie a la tesis de Clemente Palma (1897), para quien la única salida de la nacionalidad era

8 Se ha señalado que el desarrollo de esta ideología, en Europa, constituyó una reacción antiigualitaria ante el avance de las ideas de libertad y democracia; tenía como supuestos la existencia de diferencias sociobiológicas entre los grupos humanos, lo que en el Perú dio pie a la marginación de la población indígena. Portocarrero, Gonzalo: "El fundamento invisible: función y lugar de las ideas racistas en la República Aristocrática”, en Aldo Panfichi y Felipe Portocarrero (eds.): Mundos interiores. Lima, 1850-1950. Centro de Investigación de la Universidad del Pacífico, Lima, 1995, págs. 219-259.

9 Montoya, Paul: Javier Prado y el positivismo peruano. Tesis para optar el grado de magister en Historia, Universidad Nacional Mayor de San Marcos. Lima, 2003, pág. 100. 
el cruzamiento con razas superiores..$^{10}$ Los planteamientos racistas encontraron eco en la mentalidad jerárquica de las elites, aunque con el cambio de siglo sus intelectuales moderaron su racismo radical, para no eliminar la posibilidad de un destino nacional para el Perú; entonces Javier Prado señaló que había una fuerza capaz de transformar la herencia racial, y ésta era la educación. En las primeras décadas del siglo XX, jóvenes intelectuales de esa elite como José de la Riva Agüero, Francisco y Ventura García Calderón, Víctor Andrés Belaúnde y José Gálvez, encontrarían que el mundo indígena era parte importante de la nación peruana, ${ }^{11}$ considerando la necesidad de incorporarla, aunque sin abandonar la expectativa de la inmigración blanca.

En la atmósfera cultural del racismo científico fue donde el Estado restringió la ciudadanía política, a través de la reforma electoral de $1896,{ }^{12}$ impulsando el centralismo político costeño y limeño, en perjuicio de las mayorías indígenas. La disposición de que votaran sólo los alfabetos, y en sufragio directo, fortaleció la participación de un grupo mayoritariamente urbano, costeño, culto, "más en sintonía con las expectativas y los proyectos de modernización de las nuevas élites". ${ }^{13}$ De modo que al separar más radicalmente a la sociedad blanca urbana y costeña de la indígena andina, la reforma electoral modificó radicalmente las bases sociales del Estado y, con ello, el proceso de construcción de la nación. El mayor cambio se dio respecto a la elección presidencial, de modo que gracias al sufragio directo y alfabeto, los presidentes elegidos de la "República Aristocrática" fueron de la costa, ligados a intereses exportadores. La autonomía de los gamonales les permitió expandir sus haciendas a expensas de las comunidades indígenas, con la connivencia de los políticos modernos de la costa. El abuso y el abandono estatal dieron lugar a levantamientos indígenas, así como al surgimiento del movimiento indigenista. Paralelamente, los empresarios agrícolas y mineros buscaron mecanismos como el enganche,

10 Palma, Clemente: El porvenir de las razas en el Perú. Imp. Torres Aguilar, Lima, 1897.

11 Gonzáles, Osmar: Sanchos Fracasados. Los arielistas y el pensamiento político peruano. Ediciones PREAL, Lima, 1996.

12 Señala Chiaramonti que, como en la Constitución de 1860, los ciudadanos con derecho a sufragio respondían al criterio de independencia económica y el sistema electoral era indirecto, contando los departamentos andinos con más votantes que los de la costa. Según dicha autora, la reforma electoral fue para oponerse al gran poder electoral de las elites regionales y al incremento de la autonomía de las regiones frente al poder central. Chiaramonti, Gabriella: "Andes o nación: la reforma electoral de 1896 en el Perú", en Annino, Antonio (ed.): Historia de las elecciones en Iberoamérica, siglo XIX. Fondo de Cultura Económica, Buenos Aires, 1995, págs. 315-346.

13 Ibidem, pág. 340. 
con el fin de conseguir mano de obra para sus haciendas, debiendo estar ello relacionado con la abolición de la contribución personal indígena, en 1895. De modo que, a inicios del siglo XX, la mayoría de la población indígena estaba más lejos que antes de la ciudadanía real y formal, al haber sido privada del derecho de sufragio y de la condición de contribuyente por un Estado en trance de modernizarse. ${ }^{14}$

\section{Los fines, los miembros y la estructura de la Asociación Pro-Indígena}

Dora Mayer se sintió profundamente tocada por la explotación a los indígenas y por el generalizado prejuicio racial que tanto daño hacía al país; sobre lo segundo expresó que ello impedía "que todos los peruanos formen en armoniosa cooperación la prosperidad individual y colectiva! En las casas de comercio de Lima y el Callao, se amargan mutuamente la existencia los empleados por ridículas cuestiones del color, y en las provincias, desde los años que el niño va á la escuela, se pone el gamonalismo la careta del orgullo de razas, tras la cual asoma un rostro del mismo matiz como el de la casta despotizada". ${ }^{15}$ Participó en las tertulias de intelectuales organizadas por el Centro Universitario de la Universidad Mayor de San Marcos para discutir el problema indígena, en las que el estudiante de filosofía sanmarquino Pedro Zulen ${ }^{16}$ planteó la fundación de la Asociación Pro-Indígena con el objetivo de conseguir la "redención" de la población indígena. Zulen ${ }^{17}$ y Mayer constituyeron el alma de dicha organización, si bien el Comité Directivo reunió a destacados intelectuales y profesionales

\footnotetext{
14 Ibidem, pág. 346. pág. 100 .

15 Mayer, Dora: “Informaciones" en El Deber Pro-Indígena, Año I, n. o 12, septiembre 1913,

16 Sobre la base de un proyecto de Zulen, presentado al Centro Universitario, se fundó la Asociación Pro-Indígena a fines de 1909. Zulen convocó a Capelo y a Dora Mayer para integrar el Comité de la organización. Zulen, Pedro: "Bases formuladas por el señor Zulen sobre las que se fundó la Asociación Pro-Indígena”, El Comercio, Lima, 31 de enero de 1910.

17 Zulen, de origen chino, tuvo una posición marginal dentro de la racista intelectualidad criolla; desde esa posición fue desarrollando un discurso y una práctica crecientemente radicales. Zulen combatía, desde un punto de vista liberal, sistemas como el enganche, al considerar que interfería en "el libre juego de la ley de la oferta y demanda; única que hace legítima la apropiación del trabajo del obrero, y sin la cual se tendrán únicamente siervos ó esclavos ...”. De ideas liberales, democráticas y nacionalistas, su búsqueda de coherencia lo llevó paulatinamente a adoptar posiciones anti-oligárquicas como la ruptura del latifundio, e incluso anti-capitalistas, sustentadas en una filosofía moral idealista. Leibner, Gerardo: "Pensamiento radical peruano: González Prada, Zulen, Mariátegui". Estudios Interdisciplinarios de America Latina y el Caribe, vol. 8, n. ${ }^{\circ}$ 1, Tel Aviv, enero-junio 1997.
} 
limeños de clase media y alta como el ingeniero Joaquín Capelo,,$^{18}$ quien ejerció la presidencia de la asociación en forma permanente, el librepensador y director de La Voce d Italia Emilio Sequi, los historiadores Rómulo Cúneo Vidal y José de la Riva Agüero, ${ }^{19}$ los escritores Abelardo Gamarra y Marco Aurelio Denegri, el músico Daniel Alomía Robles, la joven feminista María Jesús Alvarado, entre otros. ${ }^{20}$ La Pro-Indígena estuvo integrada, además, por intelectuales y profesionales provincianos que, como delegados, dieron vida a la asociación en diversas ciudades del país. Queremos destacar el origen extranjero de los que serían sus dos principales impulsores, Zulen como secretario general ${ }^{21}$ y Mayer como directora de publicaciones; asimismo, la participación activa de dos mujeres en el Comité Directivo, Mayer y Alvarado, lo que era bastante innovador para la Lima de la época.

Zulen y Mayer fundaron la Asociación Pro-Indígena sobre el modelo de las ligas inglesas, que actuaban por iniciativa privada, obteniendo el apoyo de los simpatizantes, al margen de las instituciones del Estado y con un fin concreto, realizando denuncias y movilizando a la opinión pública sobre temas sociales, como la Liga "Anti-Slavery and Aborigenes Protection Society" de Londres, con la que mantenían importante cooperación. En opinión de Zulen, eran estas ligas "las que han hecho de la Inglaterra monárquica, una democracia práctica, que no existe en países que, como el nuestro, se titulan democráticos". ${ }^{22}$

18 Catedrático de la Universidad Mayor de San Marcos, fue senador por Junín entre 1901 y 1912, participando en la defensa de los obreros de la zona minera. Durante el primer gobierno de Benavides ocupó la cartera ministerial de Fomento, situación que aprovechó para atacar al abusivo sistema del enganche, campaña que dirigía la Pro-Indígena; derogó por anticonstitucionales el "Reglamento de locación de servicios y policía minera" del 4 de septiembre de 1903, y la Resolución Suprema de 1911; también los artículos 10, 12 y 18 del Reglamento de 15 de marzo de 1901. Capelo, Joaquín: El Deber Pro-Indígena, Año II, n. ${ }^{\circ}$ 21, junio 1914.

19 En los primeros tiempos de la Pro-Indígena, colaboraron algunos jóvenes intelectuales novecentistas, como José de la Riva Agüero, Víctor Andrés Belaúnde y Oscar Miró Quesada. Arroyo Reyes, Carlos: Nuestros años diez. La Asociación Pro-Indígena, el levantamiento de Rumi Maqui y el incaísmo modernista. LibrosEnRed, Buenos Aires, 2005, págs. 45-49.

20 Como señalaría Dora Mayer refiriéndose a Capelo, algunos conspicuos miembros de la ProIndígena hacía poco que habían descubierto la problemática indígena en el país, convenciéndose de su trascendencia. Mayer, Dora: "Discurso del sr. Pinzás contra la Asociación Pro-Indígena en la Cámara de Diputados”, en El Deber Pro-Indígena, Año I, n. ${ }^{\circ}$ 2, noviembre 1912, pág. 18.

21 Como secretario general de la Pro-Indígena, Zulen preparó comunicados, escribió artículos de denuncia del gamonalismo, se carteó con los delegados y atendió a los mensajeros indígenas.

22 Carta de Zulen a José Coello Meza, delegado de la Asociación Pro-Indígena en Cusco. Archivo Zulen, Correspondencia API, febrero 1912, carta 873. Citado por Leibner, "Pensamiento radical peruano: González Prada, Zulen, Mariátegui”. 
La Pro-Indígena se propuso como misión defender la vigencia para los indígenas de los derechos que la Constitución otorgaba a todo ciudadano (libertad de expresión, reunión, propiedad, trabajo). Para garantizarlos, recurrieron a una serie de estrategias, como la propaganda a favor de la causa indígena, incidir en la aprobación o abolición de disposiciones legales, establecer un periódico destinado a "educar" a los indígenas y una oficina especial para defenderlos gratuitamente en todo el Perú. Como señaló el delegado arequipeño radical Francisco Mostajo, "la actividad de la ProIndígena hasta hoy se ha concretado especialmente a la sostenida defensa de los derechos conculcados del indígena" ${ }^{23}$ Se aspiraba a mayor justicia y patriotismo, con lo que "la redención de esa raza no tardará en alumbrar"; ${ }^{24}$ había, pues, que terminar con esa explotación "para tener el derecho de que el Perú ocupe su lugar entre los pueblos civilizados del siglo XX" ${ }^{25}$ En términos de Emilio Gutiérrez de Quintanilla, se buscaba "la regeneración de la gran masa aborijen (sic), que ocupa el Perú con mayor derecho que nosotros" ${ }^{26}$ La misión tenía un objetivo ambicioso, promover que los propios indígenas aprendiesen a defenderse de los atropellos, para que pudiesen "resurgir a la condición de ciudadanos que la Constitución les acuerda", ${ }^{27}$ como señaló Capelo. En términos de Zulen, se trataba de "convertir a los indígenas en ciudadanos conscientes de sus derechos". ${ }^{28}$ Vemos que en el nacimiento de la organización había una visión liberal clásica, la lucha por la aplicación de las leyes y el ejercicio de derechos. Sería luego, al contacto con la explotación de los indígenas, cuando la posición de algunos miembros de la Asociación (Zulen, Chuquihuanca) se iría radicalizando. Según Mayer, fue la base moral y de respeto mutuo lo que posibilitó que lucharan juntos en la Pro-Indígena por una misma y noble causa, más allá de las diferencias políticas entre ellos, lo que demostraba su "carácter verdaderamente nacional". ${ }^{29}$

23 Mostajo, Francisco: "Contra una argumentación trivial”, en El Deber Pro-Indígena, Año I, n. ${ }^{\circ}$, enero 1913 , pág. 32.

24 Referencia al discurso del doctor Joaquín Capelo en un artículo redactado por Dora Mayer “La Junta General. El 4. ${ }^{\circ}$ año de labor de la Asociación Pro-Indígena”, en Ibidem, Año I, n. ${ }^{14}$, noviembre 1913, pág. 111.

25 Capelo, Joaquín: “El Deber Pro-Indígena” en Ibidem, Año I, n. ${ }^{\circ}$ 1, octubre 1912, pág. 2.

26 Gutiérrez de Quintanilla, Emilio: "El primero de los deberes" en Ibidem, Año I, n. . 1, octubre 1912, pág. 3 .

27 Mayer, "La Junta General".

28 Zulen, Pedro:"Texto mecanografiado de conferencia (Lima, 1910-1911)", en Arroyo, Nuestros años diez, pág. 21.

29 Mayer, Dora: "Hacia la democracia", en El Deber Pro-Indígena, Año II, n. ${ }^{19}$, abril 1914, págs. 28-29. 
El grueso del trabajo de la oficina de Lima recayó sobre los hombros entusiastas de Mayer $^{30}$ y de Zulen. La Pro-Indígena estableció un tejido social, una red moral de socios bastante disciplinada, a través de la cual fluía la comunicación entre el Consejo Directivo y los delegados en provincias y se organizaba la acción. Su estrategia central fue construir una corriente de opinión pública a través de artículos de opinión y denuncias en El Deber Pro-Indígena, así como en otros periódicos. Sesenta y dos delegados, más o menos permanentes, realizaban en sus ciudades multitud de gestiones ante las autoridades públicas (juez, subprefecto, prefecto), defendiendo judicialmente a los indígenas cuando eran despojados de sus tierras, forzados a engancharse, sometidos a la conscripción militar y a los trabajos públicos, encarcelados arbitrariamente y otras muchas formas de explotación y servidumbre, que a menudo contaban con el aval de las autoridades. Además, trasladaban a la oficina de Lima esta información, así como las quejas de los indígenas. ${ }^{31}$. Esta denunciaba los hechos más graves que "tienden á privar al indígena de su dignidad ciudadana y á despojarlo de sus propiedades, reduciéndolo á una miseria aniquiladora y matante"; ${ }^{32}$ lo hacían en la prensa, a través de conferencias, con proyectos de ley en el Congreso $^{33}$ y apoyando la redacción y gestión de memoriales que los mensajeros indígenas querían presentar al presidente de la República. Hasta donde sabemos, la Pro-Indígena apoyó, también, la fundación de algunas asociaciones posiblemente de tipo sindical, para la defensa de sus derechos, como la "Sociedad Unión y progreso de San José". ${ }^{34}$

Las quejas de los indígenas se hicieron cada vez más frecuentes, al ritmo creciente de las usurpaciones de tierras, aunque también debido a la intensa actividad desplegada por Mayer, Zulen y algunos delegados, entre

30 Como señalara Gutiérrez de Quintanilla, resultaba consolador ver que en el Perú una asociación privada y, dentro de ella, una "mujer débil por su sexo, pero de gran corazón i poderoso carácter", levantaban por primera vez el estandarte de la resurrección nacional, abordando el problema de "la regeneración de la raza aborijen (sic), que ocupa el Perú con mayor derecho que nosotros". Gutiérrez de Quintanilla "El primero de los deberes", pág. 3.

31 En 1913, Zulen informó haber recibido 456 comunicaciones de los delegados, dirigido 596 notas, 1 circular y 35 telegramas, presentado 42 recursos a la administración pública, redactado 12 memoriales para indígenas que se presentaban ante el Supremo Gobierno, tramitado 18 expedientes venidos de diversas partes del país, y dado a la prensa alrededor de 300 publicaciones. Zulen, Pedro: "Memoria del secretario" en El Deber Pro-Indígena, Año I, n. ${ }^{\circ}$ 14, noviembre 1913, págs. 115-122.

32 Gutiérrez de Quintanilla, "El primero de los deberes", pág. 3.

33 En septiembre de 1913 la Pro-Indígena acordó por unanimidad dirigir un manifiesto a la nación, exponiendo el curso que habían seguido en el Senado, en las sesiones del 8 y 18 de agosto, los proyectos de ley presentados por Capelo ante la legislatura ordinaria de 1910.

34 Mayer, Dora: "Comité Directivo", en El Deber Pro-Indígena, Año I, n. o 11, agosto 1913. 
los que destacaban Francisco Mostajo, de Arequipa, ${ }^{35}$ y Francisco Chuquihuanca, de Lampa ${ }^{36}$ Los delegados hicieron que la Pro-Indígena tuviera resonancia nacional y que no fuese sólo un proyecto de la sociedad civil limeña. Zulen conoció a Mostajo, Chuquihuanca y Modesto Málaga, a los que consideró valerosos defensores del pensamiento libre, que "laboran en silencio el Perú del futuro", combatiendo contra las tiranías locales, "contra los crímenes más inauditos que impiden que el Perú sea lo que debiera ser, un pueblo respetado por la realidad de sus instituciones democráticas". ${ }^{37}$ Señaló que, unidos por el objetivo de hacer nacionalidad y patria, socios y delegados "Despertaremos a la raza adormecida por el abuso, sin mas arma que nuestra fe arrolladora e invicta". ${ }^{38}$

\section{El país que El Deber Pro-Indígena mostró}

Dora Mayer asumió el compromiso de fundar, con sus artículos en $E l$ Deber..., "una cátedra de moralidad y conciencia pública que nos garantice la subsistencia de nuestra democracia y nuestra nacionalidad en medio de los azares de la vida colectiva". ${ }^{39}$ El Deber... publicaba las quejas para que la opinión pública conociera la amplitud y grado de los abusos. Ella escribió alrededor de dos tercios del contenido de El Deber..., ejerció la Presidencia de la asociación cuando Capelo fue ministro de Fomento en 1914, así como la "Secretaría accidental" durante 1915 y 1916 en reemplazo de Zulen, quien viajó al sur por motivos de salud y por interés en la zona, y luego fue tomando distancia de la asociación.

En El Deber... aparecen quejas y denuncias provenientes de todo el país, siendo la opresión más aguda y sistemática en las localidades en las

35 Francisco Mostajo encabezó la Liga de Librepensadores de Arequipa, y en 1900 fundó con otros el Partido Liberal de Arequipa, defendiendo la causa obrera, el socialismo, la revolución social y la igualdad; fue hostilizado por los sectores clericales y conservadores arequipeños. Arroyo, Nuestros años diez, págs. 67-68. Fue uno de los delegados más activos, luchadores, capaces y confiables de la Pro-Indígena.

36 Chuquihuanca estudió en Arequipa, iniciando campaña a favor del indio en la revista Wajcha Kuyac; en su tesis doctoral planteó la urgente necesidad de impedir la expansión del gamonalismo sobre las tierras de comunidad. Ibidem, págs. 72-73. Como delegado por Lampa de la ProIndígena, denunció los abusos de los gamonales, brindó asistencia legal a los indios y organizó comités en varias provincias de Puno, escribiendo artículos e informes.

37 Zulen, Pedro: "Revolucionarios; Sí, Revolucionarios", en El Deber Pro-Indígena, Año III, n. ${ }^{\circ} 30$, marzo 1915 , pág. 116.

38 Ibidem.

39 Mayer, "Hacia la democracia". 
que se obtenían productos para la exportación, es decir, que formaban parte del circuito de la economía avanzada. Se denuncia, así, que en las modernas haciendas azucareras y arroceras de la costa, la forma de trabajo combinaba lo asalariado capitalista con lo servil, pues utilizaban la modalidad del contrato de "enganche", sistema ilegal en el que los peones enganchados recibían adelanto de dinero para su traslado a la hacienda, debiendo trabajar para pagar la deuda a cambio de jornales insignificantes y siendo encarcelados si no cumplían; ${ }^{40}$ bajo la misma modalidad se trabajaba en la extracción de minerales (cobre, especialmente) para compañías extranjeras en la sierra central. En las tradicionales haciendas laneras de la sierra sur, en manos de gamonales, predominaban formas serviles como el yanaconaje y el pongaje; y en la zona de la selva donde se recolectaba el caucho para compañías nativas y extranjeras, los indígenas estaban esclavizados. Nos encontramos a lo largo de las páginas de El Deber..., y casi siempre del puño y letra de Dora Mayer, denuncias de los abusos y crueldades cometidos por empresas capitalistas como la compañía cauchera Casa Arana Hnos. en el Putumayo (selva) y la compañía norteamericana Cerro de Pasco Mining Co. (Cerro de Pasco), así como por hacendados costeños y gamonales serranos: las matanzas en Huancané (Puno), las del valle de Chicama (La Libertad), las de Baños (Lima), las de Zaña (La Libertad) y las de Azángaro (Puno) en el distrito de Samán en 1913 y en toda la provincia en 1916. La constante era la indefensión indígena ante atropellos que contaban con la anuencia de gobernadores, subprefectos y prefectos, jueces de primera instancia e inclusive con representantes del gamonalismo en el Congreso.

En el caso de las crueldades contra los indios del Putumayo, ${ }^{41}$ Mayer aclaró que la Pro-Indígena no denunciaba ni investigaba, pues tales acciones corrían a cargo de la Cancillería británica, debido a que la casa Arana tenía representación en Londres y habían sido empleados negros de Barbados, súbditos británicos, quienes torturaron y asesinaron indios. Pero aclaró que sí se informaban de lo investigado, para dar a conocer a la opinión pública los atentados contra la civilización que se cometían en la sel-

40 Decía Capelo que en el Perú, la esclavitud imperaba principalmente sobre los indígenas y que en los últimos años se difundía el enganche de modo descarado. Capelo, Joaquín: "Ciudadanos, no esclavos ni siervos", en El Deber Pro-Indígena, Año IV, n. * 40, enero 1916, pág. 195.

41 Según el informe del cónsul de Gran Bretaña en Pará, sir Roger Casement, de 1900 a 1911 la producción de caucho del Putumayo había alcanzado 4,000 toneladas, pero con el costo de 30,000 vidas. Basadre, Jorge: Historia de la república. Sexta Edición, Editorial Universitaria S.A., Lima, 1968, pág. 185. 
va y cómo la mencionada compañía cauchera no buscaba tanto regiones donde abundara el árbol de jebe, como aquéllas "donde hubiese mayor población de indios dóciles y fáciles de someter" como los huitoto y otros, llegando a sumar 40,000 los "operarios" indígenas forzados a trabajar en condiciones infrahumanas para la empresa. ${ }^{42}$

Sobre los abusos de la compañía minera norteamericana Cerro de Pasco Mining Company, Mayer escribió un folleto en inglés _-'El Libro Amarillo"- que se hizo circular en el extranjero, denunciando los métodos inicuos de esa empresa respecto del país y de los indígenas. El Concejo Municipal del Callao lo editó en castellano como "La conducta de la Cerro de Pasco Mining Company" pues, como señaló Mayer, era "la nación toda que debe darse cuenta del menoscabo que sufren su soberanía y dignidad por los arrogantes desplantes de algunas poderosas empresas mercantiles extranjeras". ${ }^{43}$

La problemática sobre la cual se extendió más largamente El Deber..., y con él Dora Mayer, fue la de de los comuneros indígenas de Puno, en la sierra sur, por tratarse de una población que estaba siendo cruelmente golpeada ${ }^{44}$ y también debido a que ésta oponía mayor resistencia que las otras frente a los abusos, desarrollándose por tanto conflictos sociales en torno a la propiedad de las tierras. La resistencia era posible debido a que se mantenía la organización comunal como expresión de identidad étnica y de defensa, debido al autoritarismo de las elites locales. ${ }^{45}$ Esos fueron años en los que la presión de los gamonales sobre la población indígena se incrementó ante el alza del precio de la lana de oveja y alpaca en el mercado internacional debido a la Gran Guerra y a la construcción del

42 Mayer, Dora: “Del Libro Azul”, en El Deber Pro-Indígena, Año I, n. o 8, mayo 1913, pág. 69. El título del artículo hace referencia al libro publicado por la Cancillería británica sobre el caso del Putumayo.

43 Mayer, Dora:”Bibliografía”, Ibidem, Año II, n. ${ }^{\circ}$ 19, abril 1914, pág. 32. Otras referencias a El Libro Amarillo de Dora Mayer en El Deber Pro-Indígena, en su nota "El Libro Amarillo", Año I, n. ${ }^{\circ}$ 6, marzo 1913, pág. 53, y en el artículo de María Jesús Alvarado: "La protesta", Año I, n. ${ }^{\circ}$ 8, mayo 1913, pág. 66.

44 En el contexto de la rápida expansión de las haciendas por el auge de la exportación lanera, entre 1876 y 1915 las de la provincia de Azángaro pasaron de 178 a 611, en un rápido proceso en el cual gran número de ayllus y comunidades perdieron sus tierras. Flores Galindo, Alberto: Arequipa y el sur andino: ensayo de historia regional (siglos XVIII-XX). Editorial Horizonte, Lima, 1977, pág. 102.

45 Pese a que la introducción de la propiedad privada había producido grandes diferencias socioeconómicas entre los miembros de las comunidades, subsistían algunas formas comunitarias para el acceso a zonas de pastoreo y a mano de obra. Golte, Jürgen: La racionalidad de la organización andina. Instituto de Estudios Peruanos, Lima, 1980. 
ferrocarril. Los gamonales utilizaron diversas estrategias para obligar a vender sus tierras a las comunidades indígenas, o las usurparon directamente valiéndose de grupos armados que operaban a la vista de las autoridades locales. El Deber... deja evidencia de que a la Pro-Indígena llegaron cientos de quejas de los indígenas de Puno - muchas más que las provenientes de otras regiones - y mensajeros en busca de apoyo, síntomas del explosivo malestar social en la región. ${ }^{46}$ El predominio de Puno en el terreno de la denuncia se asentaba sobre una importante experiencia anterior, la que propició entre 1867 y 1871 la "Sociedad Amigos de los Indios", aprendizaje que debe de haber influido sobre la capacidad organizativa y de denuncia de los líderes comunales casi medio siglo después. ${ }^{47} \mathrm{El}$ proceso que condujo dicha sociedad guarda innegable semejanza con el que desarrollaría la Pro-Indígena, ya que también entonces un grupo de la elite limeña estableció contacto con los comuneros indígenas a través de una red de sucursales en diversas partes del país, intentando representarlos ante el Estado en la defensa de sus derechos civiles y propiciando que desarrollasen formas de autodefensa. ${ }^{48}$ Indudablemente había dejado una huella su trabajo de sensibilización de las comunidades indígenas puneñas sobre su derecho al trabajo libre, a la igualdad y a la educación, la valorización del castellano y del conocimiento de la legislación y su estrategia de involucrar a la opinión pública a través de denuncias periodísticas, ${ }^{49}$ así como al Congreso y al presidente.

Entre 1909 y 1917 la Pro-Indígena denunció la creciente violencia en Puno, desatada por gamonales que competían por el control de tierras y

46 "Sea porque la robusta raza aymará no soporta su cruz con la misma resignación como otros de los componentes de la colectividad nacional ó porque las continuas tentativas hechas// por ella para sacudir la garra de su victimario ha exaltado más las pasiones de éste, lo cierto es que Puno figura con insistente relieve en los clamores que se dirigen a la Asociación Pro-Indígena ó, por conducto de ella, al supremo gobierno. El incesante y sistemático avance de los latifundios sobre la pequeña propiedad, comunal en su mayor parte, es allá, como en casi todo el Perú, causa de un hondo malestar social que puede conducir al definitivo desmoronamiento de las bases de existencia del Estado". Mayer, Dora: "Memoria del Secretario General", en El Deber Pro-Indígena, Año III, n. o 38, noviembre 1915, págs. 179-180. Ella elaboró dicha Memoria en reemplazo de Zulen, fungiendo como "secretaria accidental", según escribió.

47 Comunicación personal de Martín Monsalve.

48 Monsalve, Martín: "Civil(ized) Society and Public Sphere in Multiethnic Societies: Struggles over Citizenship in Lima, Perú (1850-1880)”, cap. 6 de Ph. D. Dissertation in History, State University of New York, Stony Brook, NY, 2005.

49 Dicha rebelión de comuneros dio lugar a una lucha por la opinión pública, en la que funcionarios y hacendados se esforzaron por convencer a la opinión pública limeña de la necesidad de aprobar una ley represiva, mientras que la "Sociedad Amigos de los Indios" defendió a los rebeldes señalando lo fundamental de incorporar al "indio" para la consolidación del Perú como nación. Ibidem. 
mano de obra indígenas, alertando sobre los cada vez más graves conflictos sociales a que esto daba lugar. Esa lucha intestina entre gamonales fue develada por Dora Mayer, ${ }^{50}$ denunciando particularmente a dos poderosos y rivales entre sí, Bernardino Arias Echenique y Angelino Lizares Quiñones, ambos diputados por Puno y que contaban con el apoyo de familiares en puestos de poder local. Pero además de usurpar tierras, Lizares había diseñado un proyecto político que planteaba una nueva Constitución federal del país. En 1910 Lizares consiguió falsas escrituras de venta de tierras en la provincia de Azángaro, extorsionando e incendiando las casas de los verdaderos dueños, huyendo muchos a Bolivia, mientras que otros le cedieron sus bienes para salvar la vida. Las estrategias defensivas de los indios de Huancané no se hicieron esperar, pues temiendo que les pasara lo mismo, previsoramente iniciaron juicio de deslinde ante el juez, pero Lizares se lanzó sobre Huancané con apoyo de gendarmes y de sus propios secuaces, en una modalidad de alianza que se hizo frecuente en estos años. Paralelamente, pidió en la Cámara de Diputados medidas enérgicas contra los abusos hacia los desvalidos indígenas, como el nombramiento de un delegado que se informara en Puno de los atropellos. Enfatizó Dora Mayer que este doble juego y su manejo de las autoridades locales, le permitieron engañar a los parlamentarios y gobierno de Lima. Los indios de Huancané mandaron un telegrama al presidente Leguía, quien ordenó al prefecto de Puno esclarecer lo ocurrido, pero éste envió más gendarmes a cazarlos. Luego, el gamonal Lizares pudo dirigirse tranquilamente a Lima a ocupar su curul en el Congreso. Ante ello, la Pro-Indígena publicó un memorial indígena enviado al presidente de la Cámara de Diputados, que señalaba que "mientras Lizares Quiñones deshonra con su presencia la Representación Nacional, sus empleados de Azángaro continúan en Huancané su nefanda obra de desolación y muerte, con orden de reunir hasta mil indios de Azángaro para exterminar á aquellos". ${ }^{51}$

Otro momento cumbre en las usurpaciones de tierras en Puno, fue 1913, en Samán (Azángaro), cuando el gamonal Mariano Abarca Dueñas empezó a formar su hacienda con las tierras de las comunidades, apoyado

\footnotetext{
50 Mayer, Dora: "La historia de las sublevaciones indígenas en Puno", en El Deber ProIndígena, Año IV, n. ${ }^{\circ} 48$, septiembre 1917, y Año IV, n. ${ }^{\circ} 49$, octubre 1917, págs. 285-300.

51 Extracto de un memorial firmado por sesenta comuneros de Huancané y dirigido al presidente de la Cámara de Diputados, inicialmente publicado en El Ariete el 17 de septiembre de 1910. Mayer, Dora: "La historia de las sublevaciones indígenas en Puno", en El Deber Pro-Indígena, Año IV, n. ${ }^{\circ} 48$, septiembre 1917, pág. 286.
} 
por la guardia urbana del gobernador para tener a raya a los indígenas. Estos enviaron una delegación a Lima para entregarle un memorial al presidente Billinghurst. María Jesús Alvarado los preparó para la entrevista y llevó al palacio de gobierno, tras lo cual el presidente prometió investigar. ${ }^{52}$ Pero en Samán se produjeron matanzas de indígenas, dando lugar a su rebelión y a la intervención de gendarmes y soldados. Fue así que Billinghurst nombró comisionado al sargento mayor Teodomiro Gutiérrez Cuevas, indigenista. ${ }^{53}$ El delegado de Lampa, Chuquihuanca, se unió a la comisión de Gutiérrez Cuevas, iniciándose una estrecha relación entre ambos que se habría mantenido más allá de la sublevación de 1915. En Samán, éste escuchó a los indígenas y recogió las probanzas en un voluminoso informe, despertando muchas expectativas entre éstos y la animadversión de los gamonales de la zona. El prefecto, el juez y el obispo se quejaron a Billinghurst por haber mandado a tan subversivo personaje y el gamonal Arias Echenique reclamó su salida en el Congreso. Gutiérrez Cuevas volvió a Lima, entregando su Informe al presidente, y en una entrevista a la prensa denunció a los gamonales Arias, Abarca y Lizares y agradeció el apoyo del delegado Chuquihuanca. ${ }^{54}$ Pero entonces fue derrocado Billinghurst y el informe aparentemente desapareció. Gutiérrez Cuevas fue deportado a Chile y Abarca desató una fuerte represión en Samán.

La rebelión se gestaba en la zona y el propio Gutiérrez Cuevas reapareció tiempo después en Puno transformado en el líder rebelde Rumi Maqui Ccori Zoncco ("Mano de piedra, corazón de oro"), presentándose como "General y Supremo Director de los pueblos y ejército indígenas del Estado Federal del Tahuantinsuyu". Su objetivo era realizar un levantamiento general contra el gamonalismo, dentro de un proyecto de estado federal. La rebelión de Rumi Maqui ${ }^{55}$ fue fijada para febrero de 1916, pero debió ade-

52 Álbumes de recortes de periódico y de fotos, del Archivo María Jesús Alvarado, Centro de Documentación sobre la Mujer (CENDOC-MUJER). Asimismo, comunicación personal de la secretaria de Alvarado, Dora Córdova, 1988.

53 Más de diez años atrás, ante la denuncia de mensajeros indígenas, se había nombrado a nuevas autoridades en todo Puno, entre ellas a Gutiérrez Cuevas; éste abolió los servicios gratuitos en Chucuito, siendo acusado por vecinos y autoridades locales de alentar la guerra racial y destituido.

54 Arroyo, Nuestros años diez, pág. 146.

55 La rebelión de Rumi Maqui ha dado pie a acuciosas investigaciones, destacando las de Ramos Zambrano, Augusto: Rumi Maqui. Movimientos campesinos de Azángaro (Puno), Centro de Publicaciones IIDSA-UNA, Puno, 1985; Flores Galindo, Alberto: Buscando un Inca. Identidad y utopía en los Andes, Instituto de Apoyo Agrario, Lima, 1987; Bustamante, Luis: Mito y realidad: Teodomiro Gutiérrez Cuevas o Rumi Maqui en el marco de la sublevación campesina de Azángaro (1915-1916), Memoria de Bachiller en Historia. Pontificia Universidad Católica del Perú, Lima, 1987; y Arroyo, Nuestros años diez. 
lantarse a diciembre de 1915 en vista de que los gamonales se enteraron. Medio millar de indígenas, muchos de ellos embriagados, atacó la hacienda San José del gamonal Arias Echenique, siendo masacrados por empleados de la hacienda y soldados procedentes de Arequipa y Cusco. Los indígenas enviaron un memorial al presidente Pardo, que fue publicado por Dora Mayer en un Boletín Extraordinario. ${ }^{56}$ A fines de 1916 Gutiérrez Cuevas fue apresado por las tropas del presidente Pardo y juzgado por traición a la patria, pero logró fugarse a Bolivia antes de la sentencia, después de lo cual sólo hay algunos indicios sobre sus movimientos. ${ }^{57}$ Resulta sintomática la peculiar versión de los hechos que publicó El Deber..., suscribiendo la que le enviara el delegado Chuquihuanca, amigo de Gutiérrez Cuevas y posible colaborador en el levantamiento, elaborada posiblemente con la intención de evitar que se relacionara a la Pro-Indígena con el alzamiento indígena. Dicha versión negaba la existencia de Rumi Maqui y señalaba que la rebelión había sido fraguada por los gamonales para despojar a los indígenas de sus tierras. ${ }^{58}$ Existe consenso entre los historiadores que han estudiado este tema acerca de que la rebelión de Rumi Maqui significó una crisis en la Pro-Indígena, pues dio lugar a diversas tomas de posición por parte de sus socios y delegados. Chuquihuanca apoyó a Rumi Maqui, y lo encubrió. ${ }^{59}$ Mostajo presentó un habeas corpus a favor de Gutiérrez Cuevas, por considerar que se había actuado en su contra de manera incorrecta y sorpresiva, pero se negó a encargarse de su defensa en el juicio militar que se le abrió, "porque no debe creerse que entre los miembros de la Asociación Pro-Indígena y Rumi Maqui existe conniven-

56 "Relación de los hechos realizados en Azángaro el 1. e diciembre de 1915", enviada por el delegado en Lampa, doctor Francisco Chuquihuanca Ayulo, y publicada por Dora Mayer en el Boletín Extraordinario. Dicho memorial utilizaba un lenguaje moderno, al solicitar que los dejasen en tranquila posesión de sus tierras, "con las garantías más seguras que la Constitución concede á todo ciudadano"; posiblemente Chuquihuanca participó en su redacción. Boletín Extraordinario, El Deber ProIndígena, Año IV, n. ${ }^{\circ}$ 40, enero 1916, pág. 212.

57 Bustamante presenta el expediente militar de Gutiérrez Cuevas, cuya documentación indica que éste sobrevivió más de veinte años a la sublevación. Brinda información sobre la residencia de su esposa en Lima (1930), sobre haber recibido su hija a nombre suyo la cédula de goce de retiro (1932), así como una carta de su esposa al presidente en nombre de Gutiérrez Cuevas (con un poder fechado en 1931) señalando que éste permanecía en un lugar montañoso del territorio nacional, dedicado a labores agrícolas. Habría muerto en 1937. Bustamante, "Mito y realidad", págs. 169-170, $177-179$

58 Boletín Extraordinario, Año IV, n. ${ }^{\circ}$ 40, enero 1916.

59 La relación entre Chuquihuanca y Gutiérrez Cuevas fue tan prolongada que en julio de 1937 el primero habría recibido una carta de Potosí, firmada por un "general Huayna Cápac", informándole del fallecimiento del general Rumi Maqui. Bustamante, "Mito y realidad”, págs. 169-170. 
cia; habiendo sospechas de que éste ha explotado la credulidad de los indígenas, y condenando la Asociación a los azuzadores inconscientes del pueblo y deseando que se haga la mayor luz posible en tales asuntos" ${ }^{60}$ De esa forma, tomó distancia de Gutiérrez Cuevas pero aceptó que éste era Rumi Maqui. Zulen estaba a favor de la revolución agraria, del federalismo y justificaba el levantamiento indígena. ${ }^{61}$ Dora Mayer aceptó la versión que exculpaba a la Pro-Indígena, demostrada por el hecho de que los gamonales hubiesen sido los grandes beneficiarios de la represión y de que "un par de descargas de fusilería" de la fuerza pública hubiesen podido acabar con un levantamiento. Pero expresó su desconfianza frente a las acciones de Gutiérrez Cuevas, Rumi Maqui, señalando que dicho militar tenía "locos sueños de encumbramiento", y mencionó posibles vinculaciones con el gamonal Lizares Quiñones, para "inventar" una sublevación y poder usurpar las tierras indígenas. ${ }^{62}$ Ello no deja de llamarnos la atención, en vista de que fue justamente Lizares quien en 1913 había pedido al Congreso el retiro de Gutiérrez Cuevas de Samán.

\section{Posibilidades y límites de la acción estatal}

¿Cómo respondía el Estado ante las denuncias de abusos que hacían, tanto los comuneros indígenas como la Pro-Indígena? Pues tomaba conocimiento de lo que sucedía en la sierra y la selva, pero cualquier posible acción de justicia se enfrentaba a su centralismo, pequeña dimensión y a percepciones racistas y excluyentes ante los indígenas. Como señaló Dora Mayer, por su debilidad el Estado no lograba ejercer el control sobre gamonales, caucheros, empresas extranjeras y nacionales, de modo que su reacción siempre era desesperantemente lenta $\mathrm{y}$, por lo general, estéril. Ciertamente, desde antes de la fundación de la Pro-Indígena había habido algunos esfuerzos oficiales esporádicos por proteger a los comuneros indígenas puneños. Presidentes como Eduardo López de Romaña, en 1902, y José Pardo, en 1905, habían respondido a memoriales indígenas de denun-

60 Ibidem, pág. 292.

61 Zulen había sido muy crítico del centralismo limeño y del gamonalismo y se había manifestado a favor del federalismo y de una revolución social agraria que destruyera el latifundio y permitiera la recuperación de las tierras indígenas. Esta postura quedó expresada en 1918 en su arenga a los indígenas de la parcialidad de Marco, instándoles a ser rebeldes, discurso que fuera publicado por José Carlos Mariátegui en Amauta. Leibner, "Pensamiento radical peruano".

62 Mayer, "La historia de las sublevaciones indígenas en Puno". 
cia, enviando comisionados a Chuchito el primero, ${ }^{63}$ y viajando a Puno y alentando el establecimiento de una escuela indígena adventista, el segundo. ${ }^{64}$ Billinghurst, más cercano a las demandas de los sectores subalternos por provenir del populismo pierolista y haber sido encumbrado por las masas urbanas de Lima, tuvo aparentemente muy estrecho margen de acción. Según Mayer, ofreció a la prensa inglesa investigar lo sucedido en el Putumayo y castigar las atrocidades, pero "hizo poco"; ${ }^{65}$ y si bien envió como comisionado a Gutiérrez Cuevas, no mostró reacción alguna ante su contundente Informe, en parte porque el orden político ya se le había escapado de las manos. El presidente de la Pro-Indígena, Capelo, de posición legalista como la propia Dora Mayer, celebraría la deposición de Billinghurst manifestando que la asociación había tenido dificultades para desarrollar su labor de defensa indígena durante "catorce meses de arbitrariedades y del más absoluto desgobierno"; y que confiaba que "con el respaldo de la constitución y las leyes, vuelva a ser posible la obra de liberación en que estamos empeñados; obra en que, día a día, se nos iban cerrando todos los caminos de reparación". ${ }^{66}$ Capelo agregó que los indígenas no palpaban el cambio operado por Billinghurst, dado que seguían vigentes las inicuas disposiciones del reglamento de Policía Minera (15 de marzo de 1901) y de su ampliación, el de Locación de Servicios (4 de septiembre de 1903) — base legal del enganche_- pese a que el Senado había declarado unánimemente que eran contrarias a la civilización y la cultura.

El Poder Legislativo fue un espacio al que la Pro-Indígena recurrió para promover leyes favorables a la causa indigenista y fiscalización de las denuncias. En 1911 Capelo realizó a favor de los indios numerosas denuncias en la Cámara de Senadores, entre ellas sobre los abusos cometidos en Chuchito por la conscripción militar, enrolando a menores de edad y a

63 En consonancia con los indígenas, el comisionado Alejandro Maguiña planteó medidas para la vigilancia, investigación y corrección de abusos, y la creación de escuelas en ciudades y caseríos para desarrollar hábitos higiénicos y morales en los indígenas. Álvarez-Calderón, Annalyda: “"Es justicia lo que esperamos de Su Excelencia': política indígena en Puno (1901-1927)”, en Drinot, Paulo, y Garófalo, Leo (eds.): Más allá de la dominación y la resistencia. Estudios de historia peruana, siglos XVI-XX, Instituto de Estudios Peruanos, Lima, 2005, pág. 321.

64 Esto último fue importante, pues hacía años que un presidente no viajaba en misión oficial a las provincias y, además, porque desde la época de la "Sociedad Amigos de los Indios" la educación era una aspiración indígena, así como un tema de consenso en la elite modernizadora. Monsalve, "Civil(ized) Society and Public Sphere in Multiethnic Societies".

65 Mayer, Dora: "La gravedad del asunto del Putumayo" en El Deber Pro-Indígena, Año I, n. ${ }^{\circ}$ 3, diciembre 1912, pág. 19.

66 Capelo, Joaquín: “4 de febrero de 1914”, en El Deber Pro-Indígena, Año II, n. ${ }^{\text {17, febre- }}$ ro 1914 , pág. 9 . 
casados, produciéndose además robos y atropellos. Asimismo, solicitó acción judicial contra los abusos cometidos en Puno, Oyón y Andahuaylas ${ }^{67}$ La Cámara de Diputados fue generalmente esquiva, pues tenía entre sus miembros a diputados gamonales que impedían las investigaciones de los abusos y el propio desarrollo educativo de los indígenas. Tuvo que ostentar Capelo el cargo de ministro de Fomento bajo el gobierno de Benavides, para conseguir la modificación de la legislación que hacía posible el enganche, demanda central de la Pro-Indígena, por atentar contra un derecho civil como era la libertad de trabajo.

\section{Reflexiones de Dora Mayer sobre los indios, el Estado y la nación}

Las páginas de El Deber Pro-Indígena son un espacio privilegiado desde el cual se puede acceder a la visión que los socios de la Pro-Indígena, y especialmente su directora y principal autora, Dora Mayer, construyeron sobre la población indígena y su relación con la nación. Las reflexiones de Mayer respecto a la vinculación entre la opresión de la población indígena y la nación, así como sus propuestas inclusivas, nos parecen relevantes en tanto nos informan de los contenidos del diálogo político que se entabló entre la Pro-Indígena y la población indígena. Y porque las cientos de páginas que Dora Mayer escribió con indignación moral fueron consumidas en esos años por intelectuales indigenistas de Lima y provincias y por los propios indígenas, incorporándose en alguna medida, al lado de otras influencias, a sus visiones, discursos y acciones.

En El Deber Pro-Indígena no aparece información sobre el tiraje, los lugares a los que fue distribuido ni tampoco sobre los suscriptores. Posiblemente era enviado a los delegados a nivel nacional, a prensa provinciana $^{68}$ y a una lista de suscriptores en Lima entre los que habría intelectuales socialmente sensibles, universitarios, periódicos, amistades y tal vez algunas autoridades. Mayer se dirige por momentos a los lectores, invitándolos a involucrarse con lo que ocurría a los indígenas: "Así es en Panao, en Zaña, y en mil lugares más del país...El público lector debe mirar con

67 Información de Basadre, citada en Bustamante, "Mito y realidad", pág. 20.

68 Mayer agradece a los periódicos de todo el país que reproducen sus documentos impresos o manuscritos, ayudándolos a dar mayor circulación a sus ideas y enseñanzas. Mayer, Dora: "Memoria del Secretario General", en El Deber Pro-Indígena, Año III, n. o 38, noviembre 1915, acápite La propaganda, pág. 178. 
menos indiferencia los relatos de esta clase, porque de él depende que la sanción se establezca y nos salve de un completo desastre moral". ${ }^{69}$

Desde las primeras páginas de El Deber..., Mayer buscó crear en la población urbana conciencia de que lo que le ocurría a los indios era relevante para la nación. Se dirigió, así, al "honrado público lector de Lima, el Callao y otras ciudades del territorio," que no advertía la "disolución social en que vivimos" y creía que "la prosperidad del país depende de que suba tal o cual candidato, de que se funde tal o cual sociedad patriótica ó se expresen tales ó cuales conceptos en un discurso político". ${ }^{70}$ Mayer consideraba que existía solidaridad entre los componentes de la nación, señalando que el sufrimiento de cada indígena dañaba a esa nación, de la que era parte. Combatió la idea de que el país lo conformaban sólo unos cuantos privilegiados:

"Los que se llaman la nación peruana no adivinan cuánto sufre el indio campesino, y este indio no adivina que su sufrimiento indivi//dual importa la lenta sangría y la muerte de la nación a que pertenece. El Perú se muere sin que nadie lo sienta, puesto que la idea de la nación radica sólo en el cerebro de la colectividad,$^{71}$ mientras que el gran cuerpo de la población, en cuyas venas se manifiestan los síntomas de la agonía que se aproxima, no tiene como comunicarse con el cerebro...". ${ }^{72}$

Mayer recordaba así a sus lectores la relación de mutua influencia y co-responsabilidad existente entre los miembros individuales de la nación peruana. Su visión nos remite a una antigua tradición intelectual de raíces europeas y andinas, la "tradición organicista". ${ }^{73}$ Para los organicistas, la materia no era una sustancia inerte, como para los mecanicistas, sino un vínculo con el mundo del espíritu. ${ }^{74}$ Percibimos que el marcado interés

69 Mayer, Dora: "Informaciones. Venancio Jara y Solórzano", en Ibidem, Año II, n. ․ 16, Lima, enero 1914, pág. 7.

70 Mayer, Dora: "El estado de la causa" en Ibidem, Año I, n. ${ }^{\circ}$ 1, octubre 1912, pág. 3.

71 Esta reflexión nos remite a las investigaciones de Benedict Anderson y Fernando Escalante. Anderson, Benedict: Comunidades imaginadas. Reflexiones sobre el origen y la difusión del nacionalismo. Fondo de Cultura Económica, México, 1983; Escalante, Fernando: Ciudadanos imaginarios. El Colegio de México, México, 1993.

72 Mayer, "El estado de la causa", págs. 3-4.

73 Ballón, José Carlos: "Hipólito Unanue visto por Augusto Salazar Bondy: La tradición orga-

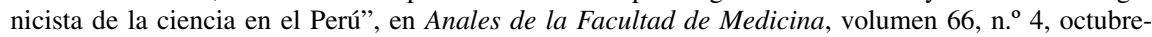
diciembre 2005.

74 Pese a que la tradición organicista fue desplazada por la mecanicista con la Ilustración, subsistió en el siglo XIX entre los médicos y filósofos románticos alemanes, primero, y los vitalistas franceses, después. Ballón, José Carlos: "Alberto Flores-Galindo y Mario Vargas Llosa. Entre la utopía indigenista y la utopía modernista. Algunas elucidaciones filosóficas". Instituto de Investigaciones del Pensamiento Peruano y latinoamericano, Universidad Nacional Mayor de San Marcos, Lima, s.a. www.pucp.edu.pe/ira/filosofia-peru/docs/ballon_galindo_vargas_llosa.pdf 
científico de Mayer iba de la mano con el lugar que le daba al espíritu, a la moral. ${ }^{75} \mathrm{Su}$ argumento sobre la solidaridad entre las partes lo encontramos también en Capelo ${ }^{76}$ lo que nos lleva a coincidir con Ballón en su planteamiento sobre que el organicismo tuvo influencia en el discurso indigenista. ${ }^{77}$

El reto que tenía ante sí la Pro-Indígena era ese: "Toda su labor tiende á poner delante de la vista de los pocos que creen ser la nación, la suerte de los muchos que son la nación sin saberlo". ${ }^{78}$ Presentó detallados informes al presidente Billinghurst sobre las masacres en el Putumayo, con el objetivo de que éste comprendiera su trascendencia para el porvenir de la nación y restableciera la justicia. Le recordaba que el Estado debía tener dominio sobre el territorio para proteger a la población, lo que el presidente anterior, Leguía, no había conseguido. Y que la debilidad del Estado dañaba la posición internacional del Perú, que no podía alegar soberanía para rechazar las gestiones judiciales de Inglaterra y EEUU sobre Putumayo, pues la soberanía era un derecho que cesaba cuando en un país "se quería asesinar a una raza entera" mostrado que la justicia peruana era impotente para contener la delincuencia de los caucheros orientales. Escribió que si Billinghurst no mostraba decisión en castigar a los delincuentes ${ }^{80}$ y en mandar misioneros

75 Sobre la pregunta de si el mundo se basa en un principio material o espiritual, o en ambos, ella responde que "donde hay materia, también hay espíritu; que la materia, en efecto, es nada más que la vida mental exteriorizada...". Mayer, Dora: "El espíritu y la materia”, en Estudios sociológicos, Tomo I, pág. 57.

76 Capelo señaló que todo en el mundo era solidario y que pocos percibían el sistema de solidaridad económica, que exigía para todos los factores de la producción una participación proporcional en los provechos. Que todo caía o caería bajo el dominio de la ciencia, como se veía en Inglaterra, nación donde todo era solidario, haciendo el Estado que lo próspero apoyase a lo adverso. Capelo, Joaquín: "Discurso del Dr. Capelo”, en El Deber Pro-Indígena, Año I, n. o. 2, Lima, noviembre 1912, pág. 10.

77 Ballón incluye entre los "indigenistas" organicistas al jesuita José de Acosta, a Guamán Poma de Ayala, Garcilaso de la Vega, Manuel González Prada, Clorinda Matto de Turner, Luis E. Valcárcel, Uriel García ("El indio no es un grupo étnico, sino una entidad moral”), José Carlos Mariátegui y a José María Arguedas. Ballón, "Alberto Flores-Galindo y Mario Vargas Llosa”, págs. 16, 19, 20.

78 Mayer, "El estado de la causa”, pág. 4.

79 Mayer, Dora: "La gravedad del asunto del Putumayo", en El Deber Pro-Indígena, Año I, n. ${ }^{\circ}$ 3, diciembre 1912, pág. 19.

80 Mayer discrepó con los seguidores del positivismo criminológico de Lombroso, para quienes la responsabilidad frente al delito se diluía; y señaló que "ya no hay culpas, donde sólo quedan conciencias amorales. Si los barbadenses ofrecen excusas para mitigar sus responsabilidades, los jefes caucheros también lo harán". Mayer, Dora: "Informaciones. Del Libro Azul", en Ibidem, Año I, n. ${ }^{\text {. . 6, }}$ marzo 1913, pág. 54. 
"latinos" al Oriente para defender a los indios de la rapacidad de los caucheros, Estados Unidos, en alianza con Inglaterra, entraría a la Amazonía "como tutor de un país que no sabe reprimir un estado de salvajismo de que protesta el mundo civilizado". ${ }^{82}$ Preveía Mayer que el avance de los sajones se produciría no sólo en lo comercial, sino también, como en este caso, en lo judicial, utilizando misiones protestantes, todo lo cual conllevaría a la desintegración de la nacionalidad.

Mayer discrepó de la eugenesia, de la supuesta superioridad blanca frente a las demás razas, que tan amplia acogida había tenido entre conspicuos miembros de la elite cultural limeña. Para ella la nación peruana no era blanca ni racialmente pura y consideraba que ésa no debía ser una aspiración nacional: "Nuestra colectividad nacional no es un pueblo de raza blanca, ni tenemos por qué poner nuestro orgullo en el color blanco ni en la pureza etnológica de nuestra sangre"; y "nuestro lugar no está en los congresos eugénicos, sino en la campaña á favor de la rehabilitación de las razas abatidas y la igualación de todas las estirpes humanas" ${ }^{83}$ Para Mayer, los "cobrizos" eran los hijos privilegiados de la patria, a la que entendía como una suerte de entidad orgánica: ella "busca entre las huestes mundiales, a sus hijos que amasó con el barro de la costa y la sombra de sus barrancos, no con la nieve de sus crestas..." ${ }^{84}$ A diferencia de las clases dirigentes, estos hijos le habían sido leales: "La Patria no tiene reproches que hacer al indio; él no la ha traicionado; él no le ha negado su sangre ni su sudor; cuando ella ha estado triste, él no ha disfrutado de placeres; cuando ella ha estado pobre, él no ha derrochado fortunas. ${ }^{85}$ Por ello, había que rehabilitar a la raza indígena y conquistarle un puesto de honor, con el auxilio de la cultura moderna, distanciándose de una visión paternalista. Y no era suficiente proteger a los "hombres de color", sino que se necesitaba

81 Para Mayer, no debían entrar a la Amazonía los misioneros enviados por Europa o Estados Unidos (se sabe que llegaron misioneros irlandeses al Putumayo), ni aunque predicasen la religión católica, por un asunto de nacionalismo, pues eran sajones. Mayer, Dora: "Informaciones. En el Libro Azul, Ibidem, Año I, n. ${ }^{\circ} 3$, diciembre 1912, pág. 30. Pese a ser luterana, Mayer habría manifestado, según relató Casement, que el protestantismo no impresionaba el alma de la raza en Perú y que no era moralizadora. Zulen, Pedro: “Memoria del Secretario. Los crímenes del Putumayo", en Ibidem, Año I, n. ․ 2, Lima, noviembre 1912, pág. 13.

82 Mayer, "La gravedad del asunto del Putumayo", pág. 21.

83 Mayer, Dora: "El Perú y la obra pro-indígena", en El Deber Pro-Indígena, Año I, n. ${ }^{\circ} 10$, julio 1913, pág. 79.

84 Ibidem.

85 Mayer, Dora: "Un canto a la raza indígena” en El Deber Pro-Indígena, Año II, n. ${ }^{\circ}$ 16, enero 1914 , pág. 3 . 
"sentar doctrina de elevación moral que constituya en dueños de los derechos humanos á los que se creen esclavos" ${ }^{86}$

Mayer criticó el centralismo político, en el que Lima y las demás ciudades eran las "únicas partes del territorio (...) para cuyo bien se parece gobernar" ${ }^{87}$ Pese a ello, discrepó del federalismo ${ }^{88}$ distinguiéndose de indigenistas como Zulen y Gutiérrez Cuevas, así como de las apetencias de gamonales como Lizares y los propietarios del periódico El Sur. Ella argumentó que el federalismo, implantado en lugares desatendidos por el Estado donde se habían desarrollado "tiranuelos", sería un atentado contra la existencia de la República y que al debilitamiento del gobierno central seguiría el robustecimiento de los feudos y, con éste, el exterminio del indio.

Esta autora denunció insistentemente la corrupción generalizada de las autoridades políticas, cuyo impune incumplimiento de la ley hacía posible que el exprefecto de Puno, Anselmo Huapaya, culpable de las matanzas de Chupa en 1910, resultara luego congresista, posición desde la que, además, defendió al coronel Ravines - prefecto de Cajamarca causante de la masacre de Llaucán de 1914_, gracias a lo cual el Congreso retiró la moción de sanción a Ravines. Mayer denunció que el Perú era "un país cuyos exgobernantes, que van á Europa para hacer vida de recreo, salen de la penitenciaría de Lima; cuyos reos acusados ejercen puestos de autoridad en toda la República, cuyos legisladores ignoran unánimemente las disposiciones legales y reglamentarias referentes á su acción..."; era un país donde el término "política" había descendido tanto que equivalía a un insulto. ${ }^{89}$

Criticó, asimismo, el personalismo, manifestando que eran las causas triunfantes y no los individuos afortunados, los que engrandecían a los países, ${ }^{90}$ y que era "doloroso ver la prosperidad de un país o de un ideal, cifradas en la persona de un gobernante particular". ${ }^{91}$

86 Mayer, Dora: "El Perú y la obra pro-indígena", pág. 79.

87 Mayer, Dora: "Lo que enseñaron las últimas huelgas", en El Deber Pro-Indígena, Año I, n. ${ }^{\circ}$, febrero 1913 , págs. 41-42.

88 Mayer, Dora: "Federalismo y feudalismo (La campaña de "El Sur" de Arequipa)", en Ibidem, Año I, n.o 15, diciembre 1913, págs. 123-124. pág. 104.

89 Mayer, Dora: "Informaciones. Fechas rojas", en Ibidem, Año III, n. ${ }^{\circ} 28$, enero 1915,

90 Mayer, Dora: "El personalismo", en Ibidem, Año I, n. 7, abril 1913, págs. 57-59.

91 Mayer, Dora: "La Sociedad Auxiliadora de la Infancia en 1915", en El Deber Pro-Indígena, Año III, n. ${ }^{\circ}$ 37, octubre 1915, pág. 171. 
Los atropellos a los indígenas la llevaron a distanciarse de los planteamientos liberales clásicos y a concluir que la representación política democrática, que había triunfado en el mundo occidental, resultaba utópica para el Perú de entonces. Su primer argumento era que los procesos electorales en el país no eran verdaderamente democráticos. Recordando los asaltos y luchas del final del gobierno de Leguía y las huelgas y paros inacabables del periodo de Billinghurst, expresó que el estado social no proporcionaba las condiciones de una legítima elección popular, debido no sólo a "la poca ilustración de las masas", sino a "la poca virtud de los candidatos"; y porque — como notaban los propios indígenas cuando eran ilustrados - la mayoría de los candidatos eran hacendados, mineros o gamonales. $^{92}$ No se cumplía la premisa del voto consciente, de la teoría democrática, pues la mayoría de la nación se componía de seres "intelectualmente inconscientes"; era minúsculo el grupo de ciudadanos que dirigía las manifestaciones electorales y estaban inspirados en intereses propios. Por ello, Mayer se manifestó en contra de delegarse la voluntad popular cada cuatro años en un mandatario ni cada seis años en un legislador, y encontró inconsistente el principio mismo de la representación nacional, pues "la opinión de la minoría puede ser justificadísima". ${ }^{33}$ Un segundo argumento fue que la representación le costaba al pueblo pensiones para los empleados públicos, quienes gobernaban en nombre de los demás bajo el mito de representar a todos y recibían homenajes a su investidura como si fuese "algo personal y suyo, y no impersonal y nacional". ${ }^{94}$ Por último, no creía conveniente la representación política pues "la idea de que alguien representa a la nación, es causa de que en los demás miembros del pueblo que es la nación, se paralicen las iniciativas cívicas, pues basta que se rodee de esplendores al representante, para que la miseria de los no representantes parezca cosa de poca importancia". ${ }^{95} \mathrm{Ni}$ el indio analfabeto se sentía representado en el gamonal, ni gobernaban las mayorías en el Perú, de modo que la representación nacional era, para Mayer, una "inútil quimera" y había que darle, a cada peruano, algo del prestigio de la representación, así fuese un "indio flagelado en una hacienda ó un diplomático banqueteado por un rey". ${ }^{96}$

92 Mayer, "Hacia la democracia".

93 Mayer, Dora: "Representación nacional", en El Deber Pro-Indígena, Año II, n. ${ }^{\circ}$ 22, julio 1914, pág. 51.

94 Ibidem, pág. 52. Vemos aquí una crítica al patrimonialismo estatal.

95 Ibidem.

96 Ibidem, pág. 53. 
Igualmente quimérica era la pretensión de que los indígenas de la selva - "los salvajes" - tuviesen la misma responsabilidad frente al Estado "civilizado" que los ciudadanos. Se había establecido que las leyes "protejen (sic) y obligan igualmente a todos", pero la verdad era que el indígena de la selva vivía fuera de la ley y que las leyes de la República no lo protegían, de modo que tampoco lo debían obligar: "nuestra ley civilizada no tiene el derecho de extender jurisdicción civil ó penal sobre seres que, así como son inaccesibles para que ella los defienda según los principios de ciudadanía, también deben quedar inaccesibles para que ella los culpe, castigue ó despoje, cosas que con frecuencia han sucedido". ${ }^{97}$ Así, discrepando ella con lo dispuesto en el Código Penal, el ignorar la ley debía eximir de responsabilidad. ${ }^{98}$ Consideraba irracional e injusto que algunas personas estuviesen bajo leyes que no conocían, siendo ese conocimiento privilegio de unos cuantos, cuando debía ser un derecho de cada individuo. Por tanto, demandó la vulgarización de los conocimientos jurídicos, de modo que se quitara a los abogados el monopolio que ejercían y, en general, se mostró a favor de la "ciencia vulgarizada" y en contra de la prestigiosa y sospechosa especialización. Así, Mayer se pronunció sobre una serie de distancias entre el diseño legal y la realidad, que hasta el presente no se terminan de afrontar y de resolver.

Tras la masacre de indígenas en Azángaro (Puno) en 1916, de la que estuvieron muy informados en la Pro-Indígena, el tono periodístico de Mayer se endureció, rechazando el racismo presente en artículos burlescos del prestigioso intelectual limeño Clemente Palma, referidos a los indígenas puneños y su supuesta sublevación para restaurar el Tahuantinsuyu. ${ }^{99}$ Esta autora atribuyó la responsabilidad de lo ocurrido en Azángaro al gobierno y a los intelectuales, señalando el daño que hacían éstos al presentar como risible la pobreza, el atraso y la impotencia de los indígenas ante los abusos. Tajantemente desenmascaró la situación: "La burla que se hace en Lima de los indios no es un mero incidente, sino todo un síntoma

97 Dora Mayer aplaude las ideas que en este sentido manifestó el doctor Genaro E. Herrera, juez de $1 .^{\mathrm{a}}$ instancia de Iquitos, en la Memoria que presentó ante la Corte Superior de esa provincia. Mayer, Dora: "Informaciones. Nuestro aplauso", en El Deber Pro-Indígena, Año III, n. 35 , agosto 1915, pág. 158. $162-164$.

98 Mayer, Dora: “Los ignorantes de la ley”, en Ibidem, Año III, n. o 36, septiembre 1915, págs.

99 Bustamante sostiene que Teodomiro Gutiérrez Cuevas, Rumi Maqui, no pretendía restaurar el Tahuantinsuyu, y que esto último habría sido una creación de personas interesadas en distorsionar su proyecto, bastante coherente, de un Estado Federal. Bustamante, "Mito y realidad". 
de la patología nacional". ${ }^{100} \mathrm{Y}$ en alusión a la racista tesis universitaria de Palma, denunció a las piezas literarias que, desafiando "la razón y el patriotismo", sostenían que a los indígenas se les debía barrer al mar, por ser elementos étnicos inferiores, y que, al igual que los pieles rojas de Norteamérica, no debían tener participación en la composición de un estado moderno. ${ }^{101}$

Con voz cada vez más urgida, Mayer instó a la población ilustrada, las clases dirigentes y las autoridades, así como a las propias poblaciones maltratadas, a que entendieran el sentido de lo que ocurría en Puno y los graves riesgos en que colocaba al Perú. Liberal y moderna, Mayer desenmascaró la esencia anti-patriótica y anti-moderna de los gamonales, "brutales conquistadores que quieren destruir la antigua organización comunal del Perú sin pensar (...) en substituirla, si fuera posible, con un orden más moderno ó adelantado". ${ }^{102}$ La cruel matanza que llevaban a cabo ponía a la Patria ante graves riesgos: la despoblación (temor común en la postura higienista), la degeneración moral, el abandono de la patria por parte de indios que encontraban refugio "fuera de la frontera nacional" e, incluso, abría la posibilidad de una intervención extranjera en este "segundo Putumayo del Perú", donde los indios eran sacrificados por gamonales desgraciados, ante la "apatía del gobierno y del pueblo peruano". ${ }^{103}$

\section{La vía legal y sus límites}

Nos preguntamos si Dora Mayer creía que los indígenas eran o no capaces de modificar su situación y, en caso afirmativo, con qué estrategias. Sus artículos en El Deber... nos muestran que reconocía que para los indí-

100 Refirió que en La Crónica y en Variedades se habían publicado dos artículos sobre el neotahuantinsuyo de Rumi Maqui, los que no juzgaba inofensivos, pues enseñaban al público que la raza indígena del Perú era "algo tan pobre en su esencia, que cuanto hace debe tomarse del lado cómico; que la pobreza, atraso, la impotencia de conquistar el progreso son causas de risa", y que era una infamia burlarse de "la mendicidad de esta raza que es culpa de los que gobiernan, de los que piensan en el Perú!". Mayer, Dora: “La sátira en su lugar”, en El Deber Pro-Indígena, Año IV, n. o 41, febrero 1916, págs. 232-233.

101 Criticó esa postura que "constituía el fundamento inmoral de existencia de la orgullosa nación norteamericana”. Mayer, Dora: “!La retribución!”, en Ibidem, Año IV, n. o 40, enero 1916, págs. 193-194.

102 Mayer, Dora: "La situación en Puno", en Ibidem, Boletín Extraordinario, Año IV, n. 40, enero 1916, pág. 202.

103 Ibidem, págs. 202-203. 
genas era muy difícil modificar la situación servil, casi de esclavos, frente a sus patrones (fuesen éstos caucheros, empresarios norteamericanos o nacionales, o gamonales), debido a su poder y al aval de las autoridades y de la mentalidad criolla. Su visión positivista, evolucionista y liberal le hacían concebir esperanzas sobre el fin de la servidumbre: "la evolución social, que ha producido el estado de la esclavitud, tiene que disolverlo á su hora, arrastrando, también despiadadamente, á todos los elementos que se le adhieran". ${ }^{104} \mathrm{Su}$ intención era crear las condiciones para el cambio, ayudando al surgimiento de una conciencia del problema y de los derechos civiles de los indígenas, en la población, las autoridades y especialmente, en los afectados. La ruta que ella señalaba a los indígenas era aprender a seguir la vía legal. Por ello era indispensable conocer las leyes, para lo cual insertaba en el periódico cuantos datos podía en pro del "enaltecimiento de las razas oprimidas" y editó un primer cuaderno (Anales) con información legal, que tuvo "bastante demanda en la República". ${ }^{105}$

En artículo dirigido a los indios de Puno, Mayer hizo recomendaciones sobre su accionar para obtener justicia. ${ }^{106}$ Respaldó la estrategia seguida por la Pro-Indígena con los indígenas, "lenta pero segura", de enseñar "a cada ciudadano o colectividad de ciudadanos" a defender sus intereses por vía legal, en su propia circunscripción territorial y judicial, dejando de lado los recursos y memoriales al gobierno, que la "apática sede del gobierno del Perú" desdeñaba. Mayer consideraba que el único poder relativamente desligado de los gamonales, por descansar sobre base independiente a las elecciones parlamentarias y presidenciales, era la Corte Suprema de Lima, por lo que la defensa indígena debía procurar llevar a esta instancia los juicios locales y las denuncias de las irregularidades cometidas por los tribunales inferiores (pues había gamonales en las Cortes Superiores de los departamentos). Debían iniciar su actividad dentro de su departamento, buscando el consejo de hombres ilustrados capaces de dirigirlos en su inexperiencia de los métodos prácticos, ${ }^{107}$ no dejándose explotar por abogados o tinterillos. Era clave que aprendieran a mover los resortes necesarios en su distrito judicial, a presionar a los ele-

104 Mayer, Dora: “Informaciones. Bibliografía”, en El Deber Pro-Indígena, Año II, n. ${ }^{\circ}$ 16, enero 1914, pág. 8 .

105 Mayer, Dora: "Memoria del Secretario General", en Ibidem, Año III, n. ${ }^{\circ} 38$, noviembre 1915, pág. 178.

106 Mayer, Dora. "A los indios de Puno", en Ibidem, Año III, n. ${ }^{\circ}$ 37, octubre 1915, pág. 171.

107 Ella señaló que sólo conocía a 3 abogados en cuya sinceridad podían confiar los indios: Chuquihuanca, Mostajo y el doctor Manuel Quiroga en Puno. 
mentos tímidos, a amedrentar a los elementos malos "que les niegan el acceso á la justicia de la Nación". ${ }^{108}$

Cabe destacar que Mayer se manifestó contraria a la que venía siendo una de las grandes estrategias de los indígenas puneños desde hacía varias décadas: el envío de mensajeros indígenas a Lima, habitualmente en época en que funcionaba el Congreso nacional, para presentarle a éste o al presidente, sus memoriales y recursos. Escribió con crudeza que "la Asociación Pro-Indígena no puede prestarse á ayudar a perpetuar esa farsa que se juega con los Mensajeros". ${ }^{109}$ Las razones que adujo fueron, en primer lugar, los pobres resultados obtenidos por éstos, apenas ser devueltos a sus localidades por el gobierno con pasaje gratuito; y en segundo lugar, el que se quedaban mucho tiempo en la capital, olvidando el motivo urgente que los había traído a Lima. Su opinión sobre los mensajeros no era muy buena, pues le parecía que no les interesaba tanto el éxito de su diligencia, como el acreditarse con los que lo mandaron; de modo que procuraban que la Pro-Indígena - que trabajaba gratuitamente por los indios - les hiciera un recurso dirigido al gobierno y consiguiera que se publicaran sus quejas en los diarios de Lima, ganando prestigio si conseguían aparecer en una foto con el presidente.

Siempre refiriéndose a la vía legal, Mayer destacó los logros en la labor de la Pro-Indígena en el desarrollo de la capacidad de autodefensa de los indígenas. Ello ocurrió a fines de 1915, apenas un mes antes del levantamiento indígena en Azángaro, que pondría a los miembros de la citada Asociación ante la disyuntiva de apoyarlo o no. Valor (o el "haberse conseguido radicar cada vez más las gestiones de defensa pro-indígena en los mismos lugares del agravio, según es mejor de acuerdo con los mandatos y el mecanismo de la ley"). ${ }^{110}$ La Pro-Indígena podía declarar que ya veía:

"los resultados de un proceso de educación cívica, que ha despertado en las distintas regiones del país un espíritu de resistencia al abuso y correcto manejo de los resortes legales, que promete terminar aunque sea en un remoto futuro, en la autonomía consciente de los pueblos de la República, acentuándose, al paso que se efectúa una paulatina descentralización en el seno de nuestra obra, el principio de la cooperación que es síntoma de los organismos sociales vigorosos y sanos". ${ }^{111}$

108 Mayer, "A los indios de Puno", pág. 172.

109 Agregaba que sólo la gran tenacidad del indio peruano podía hacer que los indígenas de Puno, después de doce años de inútiles idas y venidas, no pensasen en cambiar de método, sin ver que los poderes públicos serían tan porfiados como ellos en rechazarlos. Mayer, Ibidem, pág. 171.

110 Mayer, "Memoria del Secretario General", pág. 178.

111 Ibidem. 
Aclaró que la oficina de Lima secundaba los esfuerzos de autodefensa de los indios, "en la estricta esfera de sus atribuciones, cada vez que las autoridades políticas y judiciales de esa localidad no otorgan la suficiente protección á los derechos de los vecinos, y había que acudir al publico y al gobierno de Lima para hacer sentir la sanción á los infractores de la legalidad". ${ }^{12}$ La apuesta de Mayer por la vía legal no le impedía advertir con preocupación sobre la explosiva situación en Puno; donde, ante el desigual poderío entre el gamonal y el comunero, este último, tras décadas de infructuosa brega, podía "algún día hacerse, enfurecido, la justicia que las altas cortes y tribunales de apelación del Estado, no le proporcionan". ${ }^{113}$

\section{Actores que podían apoyar el cambio en la situación indígena}

Mayer esperaba el apoyo individual a la causa indígena, por parte de hombres ilustrados y morales, especialmente si estaban en roles políticos de congresistas, jueces, prefectos, subprefectos, párrocos, abogados y otros. Había que dejar avanzar y secundar toda iniciativa favorable a los indígenas, como el caso del valioso indígena Manuel Zúñiga Camacho, quien había hecho una obra "a favor de la instrucción y moralización de su raza", ${ }^{114}$ fomentando y dirigiendo escuelas adventistas indígenas en Puno, para formar ciudadanos productivos. ${ }^{15}$ Mayer cuestionó a "los sectarios de Lima", a los católicos, por no apoyar a Camacho, pues lo valioso no era ser de una u otra sino "la virtud viva inherente en el alma de Camacho". ${ }^{116}$ En el periódico, Mayer destaca otro ejemplo de esfuerzo moral individual vital para la nación, el de Juana Alarco de Dammert, quien a través de la Sociedad Auxiliadora de la Infancia ayudaba y educaba a los niños pobres

112 Ibidem, pág. 179. La cita se refiere a los pueblos de la provincia de Pallasca.

113 Ibidem, pág. 180.

114 Mayer, Dora: "La química social", en El Deber Pro-Indígena, Año I, n. ${ }^{\circ} 13$, octubre 1913, págs. 104- 106.

115 Una de las escuelas adventistas, en el ayllu de La Platería (Puno), fue atacada por una turba aparentemente azuzada por el obispo, ante lo cual Camacho denunció el hecho a las autoridades, postura que asumieron también Zulen y Chuquihuanca. Fonseca ha señalado que los misioneros protestantes apoyaron a la Asociación Pro-Indígena, informando de sus actividades y promoviendo la participación de los miembros de sus congregaciones en ellas. Fonseca, Juan: "Protestantismo, indigenismo y el mundo andino (1900-1930)", en Drinot y Garófalo (eds.): Más allá de la dominación y la resistencia, pág. 301 .

116 Mayer, "La química social”, pág. 105. 
de la ciudad de Lima. ${ }^{117}$ Pero previno contra la tentación del personalismo, enfatizando que así la Auxiliadora de la Infancia como la propia ProIndígena, aspiraban "á una finalidad en los destinos de la Nación superior al poder individual!". ${ }^{118}$

Mayer escribió regularmente sobre el rol de la prensa, consciente de la relevancia de obtener su apoyo en la sensibilización y formación de una corriente de opinión favorable a la justicia hacia los indígenas. Informó que la prensa de provincias era mucho más receptiva que la de Lima para tratar esa problemática, así como reproducir o comentar favorablemente artículos de El Deber..., siendo este último el caso de La Alborada de Pisco, ya que "en provincias alienta la esperanza de hallar la salvación social, mientras que en Lima se vive sin sentir las pulsaciones del pueblo". ${ }^{119}$ Señaló que una excepción era $E l$ Comercio, diario que publicó muchas veces artículos de Mayer y de Zulen, aunque dada su gran circulación tenía dificultad en ocuparse de "asuntos de interés para los pueblos pequeños de la república" ${ }^{120}$ como señaló con ligera ironía. Mientras unos pocos periódicos, como El Pueblo y La Bolsa, de Arequipa, se indignaban ante los ataques a la Pro-Indígena en la Cámara de Diputados, ${ }^{121}$ aquéllos de propiedad de gamonales (caso de El Sur), refutaban lo publicado por la asociación.

En los días álgidos de la sublevación de Rumi Maqui, Mayer tuvo claro que no bastaba El Deber... para inculcar en toda la "masa ciudadana del Perú la conciencia que le falta de la horrenda magnitud del crimen parricida que una clase social, dotada de ventajas morales y materiales, perpetra á la sombra de una indiferencia general incalificable", y dijo esperar que tal papel lo cumpliera El Comercio, "el diario mas leído dentro y fuera del país". ${ }^{122}$ Este, salvo excepciones, proporcionó información valiosa sobre la sublevación, y la mayor parte de publicaciones, tanto de Lima como de provincias, dedicaron varias páginas a los sucesos. ${ }^{123}$ Pero Dora llamó la atención sobre que justamente en Lima, donde residía "la facultad administrativa que ordena el movimiento político y la opinión ilustrada que lo encausa

117 Mayer, Dora: "La Sociedad Auxiliadora de la Infancia en 1915", en El Deber Pro-Indígena, Año III, n. ${ }^{\circ}$ 37, octubre 1915, págs. 169-171.

118 Ibidem, pág. 171.

119 Mayer, Dora: "Periodismo", en El Deber Pro-Indígena, Año III, n. o 30, marzo 1915.

120 Sobre un artículo publicado en El Comercio, el 13 de septiembre véase Mayer, Dora: "Llaucán”. Año III, n. o 36, en Ibidem, septiembre 1915, pág. 166.

121 Mayer, Dora: "Comité Directivo", en Ibidem, Año I, n. ${ }^{\circ}$ 3, diciembre 1912.

122 Mayer, “¡La retribución!”, pág. 193.

123 Bustamante, "Mito y realidad", págs. 27-28. 
y dirige", no se había hecho lo suficiente para hacer comprender al público "la enormidad de la catástrofe que desde lejos asistimos, no como simples espectadores, sino como cómplices y copartícipes en ella por las relaciones que se infieren de la solidaridad nacional". ${ }^{124}$ Contrastó la notable cobertura periodística de la Primera Guerra Mundial con la de los atentados en Azángaro, casi desconocidos por los lectores pese a que su repercusión en "el vigor y el crédito del país" sería mayor que las consecuencias de la guerra europea. ${ }^{125}$

Para Mayer, lo esencialmente peruano ("el Yo de los peruanos") debía tener precedencia sobre todo lo demás; por ello, "para no depender de la deficiente voluntad de los diarios de Lima para publicar el amplio material de correspondencias, documentos, etc. sobre la explosión de perfidia gamonalista en Azángaro", decidió publicar un Boletín Extraordinario dedicado a ello. Colocó en él toda la información posible sobre "los enemigos de la vida y la libertad de los comuneros indígenas de Puno", sobre la "defensa legitima" iniciada por éstos ante los poderes políticos y judiciales, sobre "los subterfugios y excusas ofrecidas por dichos poderes, y sobre el criterio parcializado o imparcial en todos los órganos de prensa del país". ${ }^{126}$ En un artículo analizó al detalle la cobertura periodística de los luctuosos sucesos de Azángaro, ${ }^{127}$ enfatizando que la poca prensa que había publicado la verdad, generalmente había sido por obra de los socios y delegados de la Pro-Indígena. Así, La Autonomía, dirigida por Zulen, dio la voz sobre los sucesos, publicando comunicaciones de los delegados; y La federación, dirigida por Modesto Málaga, denunció el sometimiento de la prensa arequipeña. En Lima, muchos periódicos y revistas enmudecieron, mientras que La Crónica y Variedades (Clemente Palma), se mofaron. En el sur andino, los periódicos de los gamonales (como El Eco de Puno) guiaron a la opinión pública en sentido "gamonalista", postura reproducida en $L a$ Prensa de Lima.

Residente en El Callao, Mayer fue testigo de excepción del vigoroso impulso con el que los estibadores del puerto paralizaban sus labores y obtenían la disminución de la jornada laboral. Señaló que, para mejorar las condiciones de "nuestros conciudadanos de los distritos agrícolas", había

124 Mayer, "La situación en Puno”, pág. 201.

125 Ibidem.

126 Ibidem.

127 Mayer, Dora:"El periodismo nacional ante los hechos de Azángaro", Boletín Extraordinario, en El Deber Pro-Indígena, Año IV, n. ${ }^{\circ}$ 40, enero 1916, págs.227-228. 
que "insistir en que las ventajas que conquistan los proletarios en las ciudades, se hagan extensivas á todo el país". ${ }^{128}$ Y lanzó un manifiesto a los obreros de toda la república, exponiendo la necesidad de ayudar a sus hermanos indígenas en el movimiento de "redención nacional". Se lee en $E l$ Deber... que algunas sociedades obreras de diversas ciudades expresaron su simpatía por la Pro-Indígena, y crearon la comisión de ese mismo nombre que se les había solicitado. Pero ello no fue suficiente y Mayer escribió que la problemática de la raza indígena no la entendían ni "los agitadores de ideas libertarias, que en el medio nacional aparecen desarraigados, ni los núcleos obreros agitados, que no tienen determinación de necesidades y menos preparación cultural para que esas ideas irrumpan en ellos". Aunque la Pro-Indígena había invocado "el compañerismo obrero para que se extienda á esa gran mancha", lamentablemente "las sociedades obreras se mostraron incomprensivas". ${ }^{129}$ Aunque Mayer valoraba el vigor y los logros de los obreros urbanos, veía con desconfianza la influencia anarquista, ideología a la que consideraba poco apropiada para el medio peruano, y encontraba que los obreros no entendían la importancia de apoyar a los indígenas. Tal vez un motivo adicional para su rechazo a la venida de mensajeros de Puno fue que algunos de los que permanecieron largo tiempo en Lima, tomaron contacto con núcleos obreros librepensadores y anarquistas; aunque Leibner considera que dicha relación "andinizó" al anarquismo peruano. ${ }^{130}$

\section{Los dilemas de la opresión indígena}

Dora Mayer mostró toda su vida una tajante oposición a la violencia y al belicismo; ya en 1914 había calificado a la Gran Guerra como un "funesto retroceso cultural á que asiste atónita la generación presente", que perjudicaba la labor de paz y armonía que sostenían asociaciones como la

128 Mayer, "Lo que enseñaron las últimas huelgas", pág. 41. pág. 75 .

129 Mayer, Dora: "Un tributo a la causa" en El Deber Pro-Indígena, Año I, n. o 9, junio 1913,

130 Gerardo Leibner ha investigado el proceso a través del cual los anarquistas limeños se fueron involucrando con el tema indígena, señalando que se dieron posiciones paternalistas, de ortodoxia y finalmente de "andinización" del anarquismo a través de la idealización del Tahuantinsuyu como comunismo, expresado en el Comité Pro-Derecho Indígena Tahuantinsuyu. Leibner, Gerardo: " $L a$ Protesta y la andinización del anarquismo en el Perú, 1912-1925”, en Estudios Interdisciplinarios de América Latina y el Caribe, Tel Aviv, enero-junio 1994, vol. 5, n. ${ }^{\circ} 1$. 
Sociedad Antiesclavista de Londres. ${ }^{131}$ Entonces escribió que esa contienda no disminuiría el celo de los que luchaban a favor de ideales humanitarios, sino más bien se intensificaría a la vista del dolor innecesario. ¿Cuál fue su postura ante la resistencia social? Las convulsiones sociales de esos años y la consiguiente represión ¿variaron en algo tal postura? Mayer escribió en abril de 1913 sobre la huelga de los trabajadores agrícolas de Chicama, que ese movimiento "pudo llegar á ser un poderoso impulso de reacción contra el estado abyecto en que gimen nuestras masas indígenas..."; ${ }^{132}$ no debe llamarnos la atención, pues la huelga era un mecanismo aceptado por las democracias modernas de Europa y los Estados Unidos. No así la insurrección. Sin embargo, creemos que las masacres y usurpaciones crecientes en Puno, unido a la apatía del Estado, la hicieron entender y, en alguna medida, justificar la insurrección indígena. A fines de 1913, a raíz de algunas muestras de resistencia indígena en Azángaro, escribió que el indio procedía así por ignorancia y que hombres públicos y periodistas deberían recordar que auxiliarlo y enseñarle era "su deber como peruanos"; y preguntó agudamente: “ ¿es justo que se reprima solamente la insurrección, y no los males que empujan a ella? ¡Protestamos de un modo tan estéril de establecer y mantener el orden en la República!". ${ }^{133}$

En noviembre de 1914, a raíz de la venida a Lima de mensajeros indígenas de Samán, Mayer criticó que el gobierno se limitara a devolverlos a su tierra pagándoles el pasaje, gesto "sin alcances reparadores", ${ }^{134}$ y se preguntó si llegaría el momento en que esos mensajeros sentirían que "el Perú no sólo era una región de sombras..." o si, caso contrario, nacería en ellos "la chispa redentora que les proporcione valor y energía para conquistar la libertad y la justicia que les corresponde, aunque la indiferencia de sus hermanos se las niegue?". Su "Amén, que así sea"135 lo interpretamos como aceptación y esperanza en que los propios indios conquisten su libertad y la justicia, con un tono que nos hace sospechar que esta vez no se refería a la "vía legal".

131 Entre la que asumimos que consideraba a la Asociación Pro-Indígena. Mayer, Dora: "Informaciones. Notas Bibliográficas", en El Deber Pro-Indígena, Año II, n. ${ }^{\circ} 26$, noviembre 1914, pág. 88.

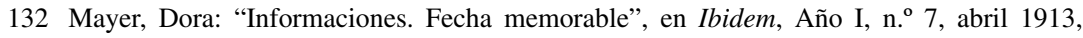
pág. 61.

133 Mayer, Dora: "Informaciones”, en Ibidem, Año I, n. 13 octubre 1913, pág. 110.

134 Mayer, Dora: "Informaciones. Los industriales de la sal en Azángaro", en El Deber ProIndígena, Año II, n. ${ }^{\circ} 26$, Lima noviembre 1914, pág. 87.

135 Ibidem, pág. 88. 
Un mes más tarde se quejó de la consternación de cierta prensa local ante el asesinato por manos de una "turba", de un "caballero" en la plenitud de su vida, cuando no se preocupaban del asesinato impune de tantos indígenas en Chicama o en Azángaro; y sentenció: "Las fechas rojas de la tiranía traen las fechas rojas de la rebeldía..." ${ }^{136}$ En septiembre de 1915 informó El Comercio que se habían sublevado 1500 indígenas de la selva, ante el tráfico de mujeres y niños que realizaban unos maleantes en el Alto Ucayali; entonces, Mayer manifestó que debería castigarse con la muerte a los que cometían el monstruoso delito de arrebatar a los indios sus hijos. Agregó que por más que se trataba de formar en las personas el concepto de la justicia, haciéndoles ver "que las sublevaciones de los salvajes son provocadas por causas suficientes, nuestros buenos amigos civilizados menean la cabeza y dicen: 'es deplorable que á estos indios no se les pueda tratar de mejor manera, pero son tan salvajes que no hay mas remedio sino exterminarlos '”, ${ }^{137}$

El optimismo de Mayer ante los logros de la lucha humanitaria pacífica, se enfrentó a los abusos de los poderes locales, la corrupción de los funcionarios estatales y la indiferencia de gran parte de la prensa y de la sociedad "moderna" ante el desangramiento y muerte de la nación peruana. Encontró explicaciones, que compartió con sus lectores, para las causas de la rebeldía indígena, no sin cierto desaliento ante "el fracaso, la esterilidad de las luchas humanitarias...". ${ }^{138}$ Días antes de la rebelión de Rumi Maqui, prometió persistir en la causa de redención de los indígenas, a la que consideraba doblemente "grandiosa" tanto por lo inmenso de los obstáculos como por el extraordinario fin: nada menos que "el resurgimiento de la verdadera patria peruana, legada á las generaciones del presente por los incas...". ${ }^{139}$ Y advirtió que la pasividad del gobierno podía dar lugar a que el indio de Puno, después de muchas décadas de infructuosa brega, "busque algún día hacerse, enfurecido, la justicia que las altas cortes y tribunales de apelación del Estado, no le proporcionan”. ${ }^{140}$

136 Mayer, Dora: “Informaciones. Las fechas rojas”, en El Deber Pro-Indígena, Año II, n. 27, diciembre 1914, p. 96.

137 Mayer, Dora: "Revista del mes. Sublevación de salvajes en el Ucayali”, en Ibidem, Año III, n. ${ }^{\circ} 36$, septiembre 1915 , pág. 166.

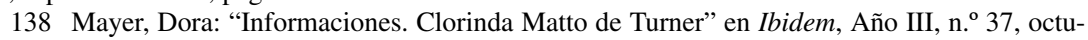
bre 1915, pág. 173.

139 Mayer, Dora: “Conclusión” en Ibidem, Año III, n. 38, noviembre 1915, pág. 183.

140 Mayer, Dora: "Memoria del Secretario General”, pág. 180. 
Mayer era consciente de que la violencia dejaba sin opción a la vía legal y que aparecía el fantasma de la sublevación indígena, a la que consideraba en parte una posibilidad real y, en parte, producto del temor de la culpable conciencia de los gamonales. Señaló con preocupación que el más hondo problema que tenía ante sí la Pro-Indígena, era saber que en el punto al que se había llegado, se abrían tres opciones "con perspectivas igualmente funestas: la sumisión indígena a despiadados patrones; la sangrienta revancha de los indios; o la sofocación de la revuelta indígena por secuaces de gamonales y fuerzas públicas". ${ }^{141}$ Mayer nunca manifestó su apoyo a la sublevación; sí explicó sus causas y, hasta un punto, justificó que fuese a ocurrir, para luego negar que se hubiera producido. Pese a ello, en el mes de la sublevación de Rumi Maqui, dedicó elogios al valiente chuncho "capaz de esas feroces reacciones contra el despotismo y abuso que ojalá fueran en todas partes del Perú valla potente contra el avance de la iniquidad y la corrupción de presuntos magnates". ${ }^{142}$

\section{Reflexiones finales}

La Asociación Pro-Indígena se disolvió en 1916, en parte porque la sublevación de Rumi Maqui dejó poco espacio para la vía legal, dando paso a posturas divergentes entre los miembros: básicamente legalista la de Mayer y Capelo, y radical, la de Zulen y Chuquihuanca. Casi cien años después, nos volvemos a preguntar sobre el impacto social que logró la asociación. Alguna información aparece en el propio El Deber Pro-Indígena: están tanto las opiniones favorables de Billinghurst y sir Roger Casement sobre su labor de educación a la opinión pública, ${ }^{143}$ como las quejas del gerente de la Cerro de Pasco sobre dificultades para hacer cumplir a los enganchados sus compromisos, pues la asociación les había informado que no estaban obligados a pagar una deuda con su trabajo. ${ }^{144}$ La propia Dora Mayer menciona algunos logros, como que por el apoyo que daban a las

141 Ibidem.

142 Mayer, Dora: "Dos palabras de la autora sobre El drama de la selva", en El Deber ProIndígena, Año III, n. ${ }^{\circ} 39$, diciembre 1915, pág. 187. En dicha obra, publicada entre 1916 y 1917, caracterizó a los chunchos como peruanos altivos y capaces de echar a temblar a los abusivos hacendados. 143 Zulen, Pedro: "Memoria del Secretario. Los crímenes del Putumayo", en Ibidem, Año I, n. 2, noviembre 1912, págs. 12-13.

144 Referido en Mayer, Dora:"Bibliografía”, en Ibidem, Año III, n. o 34, julio 1915, pág. 149. 
personas injustamente tratadas, "las empresas capitalistas se ven con frecuencia obligadas á prestar a los reclamantes una atención y concederles ventajas que de otro modo no les otorgarían, para evitar las vergüenzas, siquiera, de una denuncia seria". ${ }^{145}$ Y refiere el éxito en las campañas contra el enganche, y contra la obligatoriedad del cargo de mayordomo en las fiestas religiosas. ${ }^{146}$

Pero su impacto sobre la organización de la propia población indígena, de la que se erigió en una suerte de representante ante el Estado, en un "cuerpo protector extraño a ella", ${ }^{147}$ fue percibido durante los años siguientes, de mayor radicalismo político, como indigenismo asistencialista, especialmente por José Carlos Mariátegui. ${ }^{148}$ Hoy podemos aquilatar la magnitud de las acciones que realizó y de las que echó a andar, así como el importante debate de ideas que generó. Sus acciones, de las que la propaganda fue la estrategia central, ${ }^{149}$ desnudaron la ficción del Perú como país moderno, mostrando lo que no se quería ver: la condición de ciudadanos de segunda detentada por los indígenas, explotados por gamonales, caucheros, gendarmes y autoridades locales; la vigencia de formas laborales serviles pre-capitalistas; y la debilidad y corrupción del Estado. Posibilitaron que se formase en los lectores urbanos y en la propia población indígena, la percepción de un mismo problema - la servidumbrereiterado mil veces en todo el país. Comprometieron el respaldo de no pocos intelectuales y universitarios en Lima y provincias. Pero sobre todo, posibilitaron la auto percepción de una identidad indígena colectiva, que

145 Mayer, Dora: Un caso de accidentes de trabajo", en Ibidem, Año III, n. ${ }^{\circ}$ 38, noviembre 1915, pág. 182.

146 La Pro-Indígena escribió sobre los gastos onerosos que realizaban los indígenas para celebrar las fiestas religiosas, recurriendo en ocasiones a hipotecas y préstamos de enganchadores, y denunciaron que las autoridades eclesiásticas y civiles les imponían penas si no participaban. Zulen presentó el problema en 1914 ante el gobierno, el cual dio una resolución suprema que señalaba que no era obligatorio el cargo de mayordomo de fiestas y prohibía la ingerencia de autoridades en el cargo, encargando vigilar abusos a los prefectos. La Pro-Indígena pidió a la prensa y a los amigos de su causa, su divulgación a los indígenas. Mayer, Dora: "Informaciones. Las fiestas religiosas”, en Ibidem, Año II, n. ${ }^{\circ} 24$, Lima octubre 1914.

147 Mayer, "Lo que ha significado la Pro-Indígena”, pág. 20.

148 Mariátegui, más interesado en conjugar socialismo e indigenismo, trató muy superficialmente a Zulen y a la Pro-Indígena, considerando el indigenismo humanitario como ineficaz pues sólo "sirvió para contrastar, para medir, la insensibilidad moral de una generación". Leibner, "Pensamiento radical peruano: González Prada, Zulen, Mariátegui”.

149 "El método principal y, por falta de medios económicos y otros auxilios, casi único, que ha empleado la Asociación Pro-Indígena en la prosecución de su campaña reformadora, ha sido la publicidad". Mayer, Dora: "Las comunicaciones ofrecidas a El Comercio", en El Deber Pro-Indígena, Año IV, n. ${ }^{\circ} 43$, abril 1916, pág. 247. 
daría pie a nuevas formas de relación, como lo demuestra la historia del Comité Pro Derecho Indígena Tahuantinsuyu (1920-1923), directo descendiente de la Asociación Pro-Indígena. En suma, todo ello debe de haber fortalecido la capacidad indígena de auto representarse y de defenderse.

Recibido el 24 de junio de 2008 Aceptado el 8 de noviembre de 2008 